Article

\title{
Extracellular Matrix Derived from High Metastatic Human Breast Cancer Triggers Epithelial-Mesenchymal Transition in Epithelial Breast Cancer Cells through $\alpha v \beta 3$ Integrin
}

\author{
Renata Machado Brandão-Costa ${ }^{1}\left(\mathbb{D}\right.$, Edward Helal-Neto ${ }^{1}$, Andreza Maia Vieira ${ }^{2}$, \\ Pedro Barcellos-de-Souza ${ }^{3}$, Jose Morgado-Diaz ${ }^{3}$ and Christina Barja-Fidalgo ${ }^{1, *}$ \\ 1 Laboratory of Cellular and Molecular Pharmacology, Department of Cell Biology, IBRAG, Rio de Janeiro \\ State University, 20551-030 Rio de Janeiro (RJ), Brazil; renata_machado88@hotmail.com (R.M.B.-C.); \\ edwneto@gmail.com (E.H.-N.) \\ 2 Laboratory of Endothelial Cell and Angiogenesis, IBRAG, Rio de Janeiro State University, \\ 20550-900 Rio de Janeiro (RJ), Brazil; deza.jpa@gmail.com \\ 3 Cellular and Molecular Oncobiology Program, Instituto Nacional de Câncer, 20231-050 Rio de Janeiro (RJ), \\ Brazil; pedrobsouza@gmail.com (P.B.-d.-S.); jmorgado@inca.gov.br (J.M.-D.) \\ * Correspondence: barja-fidalgo@uerj.br; Tel.: +55-21-2868-8298; Fax: +55-21-2868-8629
}

Received: 1 April 2020; Accepted: 11 April 2020; Published: 23 April 2020

\begin{abstract}
Alterations in the composition and architecture of the extracellular matrix (ECM) can influence cancer growth and dissemination. During epithelial-mesenchymal transition (EMT), epithelial cells assume a mesenchymal cell phenotype, changing their adhesion profiles from cell-cell contacts to cell-matrix interactions, contributing to metastasis. Breast cancer cells present at different stages of differentiation, producing distinct ECMs in the same tumor mass. However, the contribution of ECM derived from metastatic tumor cells to EMT is unclear. Here, we showed the mechanisms involved in the interaction of MCF-7, a low-metastatic, epithelial breast cancer cell line, with the ECM produced by a high metastatic breast tumor cell, MDA-MB-231 (MDA-ECM). MDA-ECM induced morphological changes in MCF-7 cells, decreased the levels of E-cadherin, up-regulated mesenchymal markers, and augmented cell migration. These changes were accompanied by the activation of integrin-associated signaling, with increased phosphorylation of FAK, ERK, and AKT and activation canonical TGF- $\beta$ receptor signaling, enhancing phosphorylation of SMAD2 and SMAD4 nuclear translocation in MCF-7 cells. Treatment with Kistrin (Kr), a specific ligand of integrin $\alpha \mathrm{v} \beta 3$ EMT induced by MDA-ECM, inhibited TGF- $\beta$ receptor signaling in treated MCF-7 cells. Our results revealed that after interaction with the ECM produced by a high metastatic breast cancer cell, MCF-7 cells lost their characteristic epithelial phenotype undergoing EMT, an effect modulated by integrin signaling in crosstalk with TGF- $\beta$ receptor signaling pathway. The data evidenced novel potential targets for antimetastatic breast cancer therapies.
\end{abstract}

Keywords: breast cancer; extracellular matrix; epithelial-mesenchymal transition; integrin signaling; disintegrin

\section{Introduction}

Breast cancer is a heterogeneous disease with a variety of clinical and histological forms. The diversity of malignant cell subtypes indicates the need to identify different molecular marks and therapeutic approaches for breast cancer $[1,2]$. Furthermore, breast cancer remains the second cause of cancer-related death in women, most of them due to metastasis [3,4]. Therefore, it is essential to determine how the metastatic process is regulated in order to identify potential targets for repressing it. 
During metastasis, tumor epithelial cells must acquire a migratory profile assuming a mesenchymal phenotype. The epithelial to mesenchymal transition (EMT) encompasses a well-coordinated series of molecular changes that lead epithelial cells to lose E-cadherin expression, acquire increased vimentin, fibronectin, and $\mathrm{N}$-cadherin expression, and rearrange cortical actin structures, increasing their migratory capacity, characteristics of mesenchymal cells [5,6]. Considered the main inductor of EMT in tumor cells, TGF- $\beta$-through the activation of their receptors-regulates two different pathways. The non-canonical pathway is related to the activation of focal adhesion kinase (FAK), ERK/MAPK, and AKT signaling. While the canonical pathway is initiated by the phosphorylation of the cytoplasmic signaling molecules, SMAD2 is followed by recruitment and activation of R-SMAD (SMAD3 associated with SMAD2). This complex is phosphorylated and then associates with SMAD4 through the MH2 domain, triggering its translocation to the nucleus. These two signaling pathways regulate the transcription of different genes that culminate in the characteristic morphological and functional changes of EMT $[7,8]$.

The crosstalk between TGF- $\beta$ receptors and other receptors, such as integrin, can modulate EMT in different cell types [9]. Integrins are transmembrane adhesive receptors that are able to integrate cells into their microenvironment through their binding to the extracellular matrix (ECM) [10]. Integrin activation modifies actin cytoskeleton dynamics, leading to integrin clustering in focal adhesion complexes and tyrosine phosphorylation of FAK [11]. They can regulate different cell functions, including EMT, through their crosstalk with other membrane receptors $[9,10]$. In human breast cancer cells, $\alpha v \beta 6$ and $\alpha v \beta 1$ integrins mediate tenascin-C-induced EMT through a pathway that involves FAK phosphorylation and Src activation, a decrease in E-cadherin expression, and increased cell migration [12,13]. The presence of $\alpha \mathrm{v} \beta 3$ in MCF-7 cells has been reported, and its expression in breast cancer has been described to be important in response to thyroid hormone, controlling tumor growth [14-16]. However, the role of $\alpha \mathrm{v} \beta 3$ integrin in breast cancer progression is still unclear.

The switch from cell-cell contacts to tumor cell-ECM interactions is typical in EMT [17]. ECM is a dynamic three-dimensional combination of proteins, glycoproteins, and proteoglycans [18] that acts as a scaffold, immobilizing soluble factors and coordinating signals transduced through both growth factors and integrin receptors [19]. Tumor-derived ECM can be remodeled by MMPs released by tumor cells, and the modifications in its composition and architecture may influence cancer growth and dissemination [20]. The specific association of cells with the ECM may provide contextual information that controls differentiation, migration, or survival [19]. Therefore, the biochemical and biophysical properties of the ECM should be considered when examining tumor behavior and therapeutic interventions. Studies using isolated ECM components or tumor fragments have highlighted the role of individual ECM proteins on the breast tumor cell EMT-like phenotype, favoring migration and metastasis [4,21-25]. Soluble tenascin C induces EMT in different breast cancer cell lines through alpha V integrin [13]. Additionally, fibronectin is increased in tumors, promoting tumor growth [26], invasion [27], and limiting tumor cell responsiveness to therapy [28].

Although it is known that certain matrix glycoproteins are up- or down-regulated in tumor matrices during cancer cell transformation [25], evidence of the direct effect of breast cancer metastatic tumor-derived ECM on the phenotypic profile of breast cancer cells with an epithelial phenotype is not available in the literature.

In the present work, we analyzed the effect of a decellularized, multi-component ECM derived from an aggressive human breast cancer cell line (MDA-MB-231) on a human breast cancer cell line with an epithelial phenotype (MCF-7). Our results showed that MDA-ECM triggered EMT in MCF-7 cells, decreasing cell-cell contacts and E-cadherin expression and increasing the expression of mesenchymal cell markers and migration in MCF-7 cells. These effects were mediated by the crosstalk between integrin $\alpha \mathrm{v} \beta 3$ and TGF- $\beta$ pathways. 


\section{Results}

\subsection{Differences in the Composition among Matrices Produced by MCF-7 and MDA-MB-231 Cells}

First, we identified matrix glycoproteins in ECMs produced by MCF-7 and MDA-MB-231 cell cultures. Data analysis showed that the two tumor cell-derived ECMs strongly differed in terms of the amounts of some ECM proteins. Relative to the content found in MCF-ECM, the matrix produced by MDA-MB-231 cells presented increased levels of tenascin-C (TN-C) and laminin (LN) and a less effective increase in osteopontin (OPN) and vitronectin (VT). Optical density ratio ranging from MCF-ECM:MDA-ECM was 1:11 fold in TN-C, 1:6 fold in LN, 1:4 fold in OPN, 1:2 fold in VT; and lower amounts of fibronectin (FN) 1:0.6 fold in FN (Figure 1).

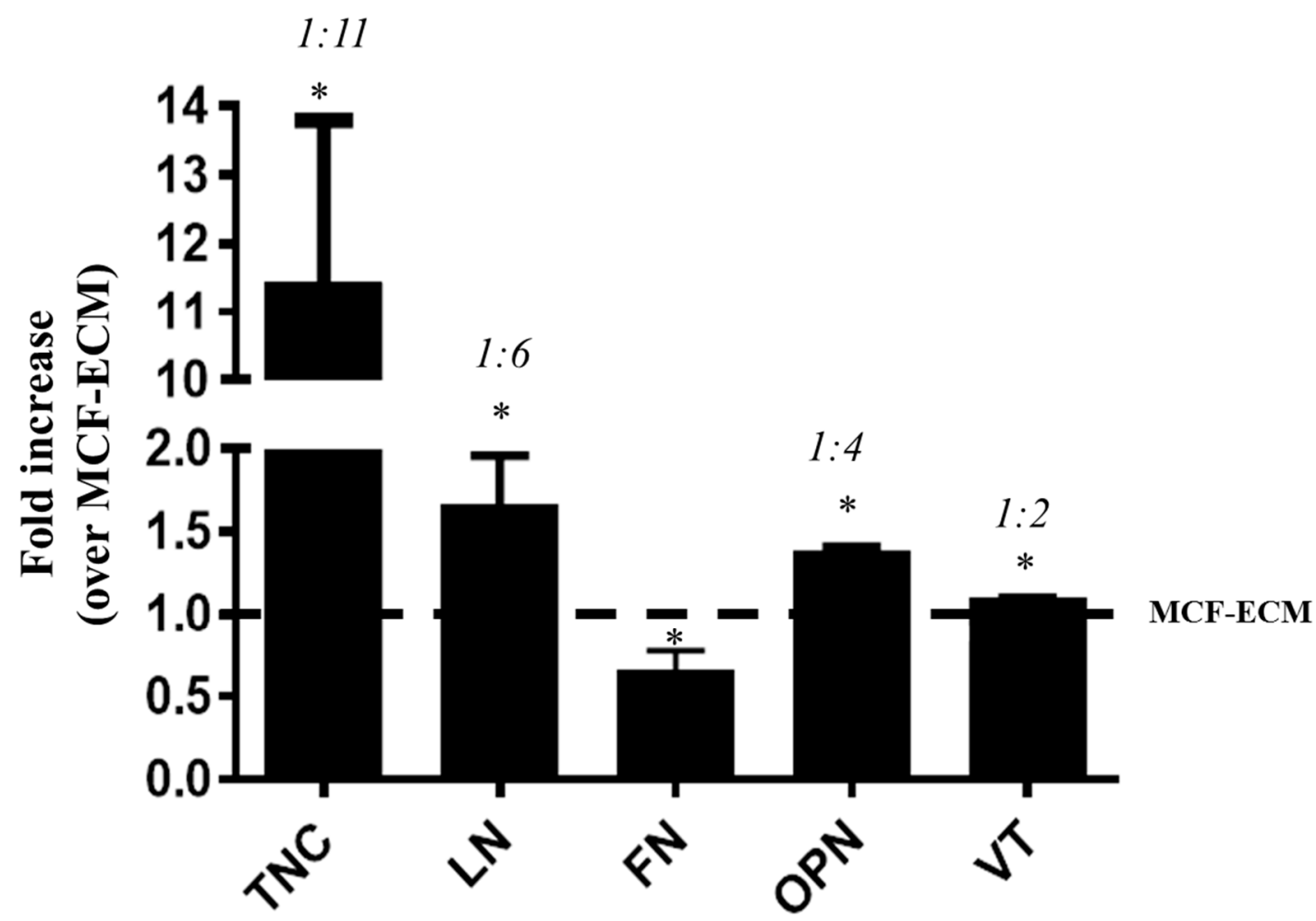

Figure 1. Differences among breast cancer cell-derived matrices. MCF-7 or MDA-MB-231 cells were grown in standard conditions for $72 \mathrm{~h}$, and the respective derived extracellular matrices (ECMs) were obtained, as described in the Methods section. The contents of tenascin-C (TN-C), laminin (LN), fibronectin (FN), osteopontin (OPN), and vitronectin (VT) were assayed by indirect ELISA. The matrix protein content of MDA-ECM is shown as the fold increase relative to MCF-ECM. Numbers at the top of the plots represent an optical density ratio ranging from MCF-ECM:MDA-ECM. The plot is the mean of 3 independent experiments $\left({ }^{*} p<0.05\right)$.

\subsection{Interaction with MDA-ECM Induced EMT-Associated Changes in MCF-7 Cells}

Specific ECM proteins have been reported to induce morphological changes in MCF-7 cells, triggering EMT [12,13,23,29-31]. The time of treatment has been reported to be critical for inducing EMT, varying with the stimulus. We observed that, after $48 \mathrm{~h}$, while the MCF-7 cells treated with TGF- $\beta 1$ changed their morphology, losing cell-cell contacts $\left(^{*}\right)$, the cells cultured on their own matrix (MCF-7-ECM), used as controls, were arranged as large clusters, with tight intercellular connections $\left({ }^{*}\right)$. The MCF-7 cells cultured onto MDA-ECM also presented an arrangement in large clusters more similar to controls but different from TGF- $\beta$-treated cells since they seemed to maintain looser intercellular connections $\left(^{*}\right)$ (Figure 2A). Besides, Figure 2B-E show that MCF-7 cells seeded on MDA-ECM for $48 \mathrm{~h}$ 
presented a slight decrease in E-cadherin and an increase in N-cadherin expression when compared to control (Figure 2B). No differences in the expression of fibronectin or $\alpha$-SMA were observed.

A
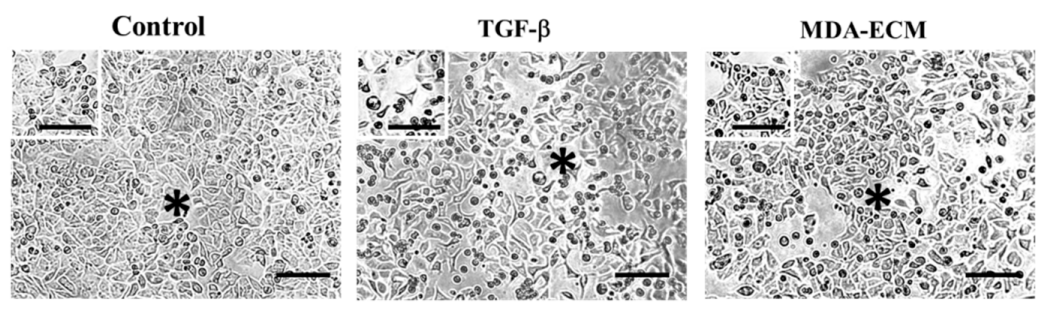

B
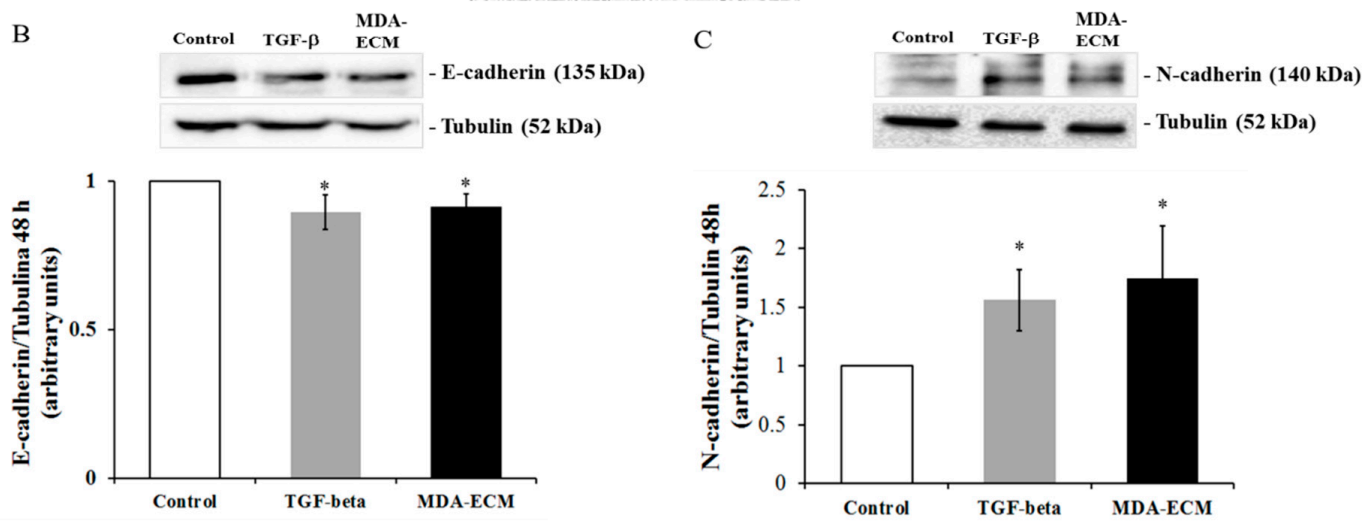

$\mathrm{D}$

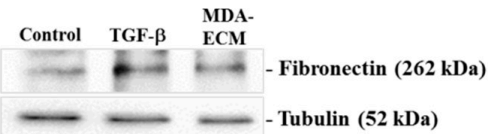

E
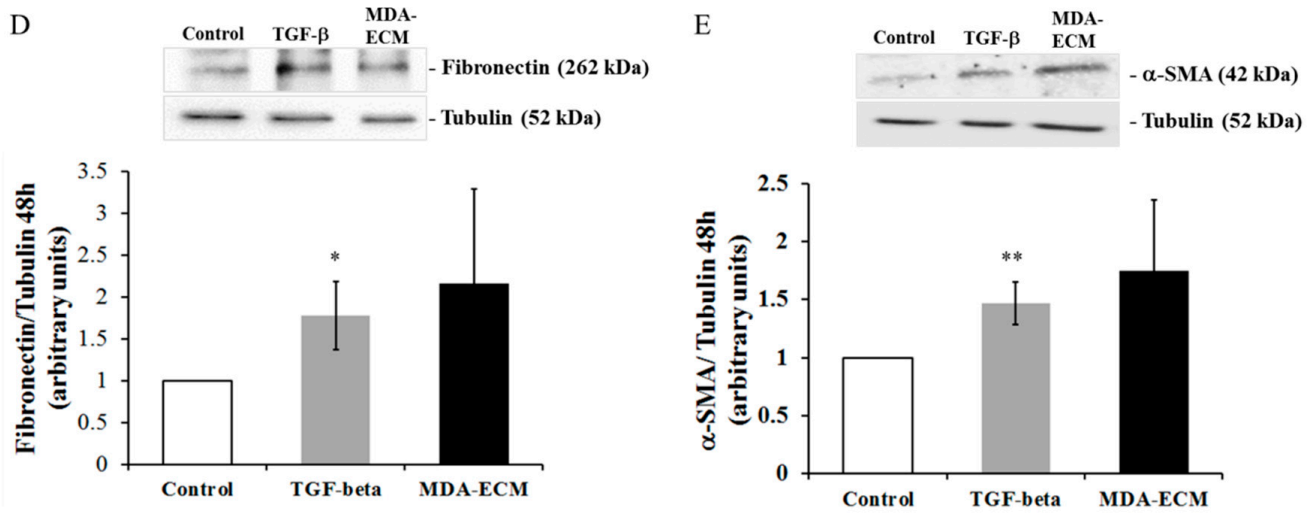

Figure 2. MDA-MB-231-derived ECM promoted a slight decrease in E-cadherin expression in MCF-7 cells in $48 \mathrm{~h}$. MCF-7 and MDA-MB-231 cells were cultured in standard conditions for $48 \mathrm{~h}$, and decellularized ECMs were obtained, as described in Methods. MCF-7 cells were cultured onto MDA-ECM or onto their own matrix with TGF- $\beta 1(10 \mathrm{ng} / \mathrm{mL})$ for $48 \mathrm{~h}$. (A) Cell morphology was analyzed, and representative images were obtained at 40× magnification. A black asterisk indicates lost or remaining intercellular connections. Scale bar: $20 \mu \mathrm{m}$ (B-E) Lysates of MCF-7 cultured as described for $48 \mathrm{~h}$ were immunoblotted with anti-N-cadherin (B), anti- $\alpha$-SMA (C), anti-fibronectin (D), and anti-E-cadherin (E) antibodies. The results are shown as the mean fold increase relative to the control (MCF-ECM), and bars represent the mean \pm SD calculated from 3 individual experiments $\left({ }^{*} p<0.05\right.$ and $\left.{ }^{* *} p<0.01\right)$.

However, MCF-7 cells seeded on MDA-ECM for $72 \mathrm{~h}$ presented an increase in the number of cells with a spindle-shaped morphology compared with that observed after $48 \mathrm{~h}$ (Figure 3A). Besides, MCF-7 cells cultured onto MDA-ECM for $72 \mathrm{~h}$ showed increased expression of $\mathrm{N}$-cadherin, $\alpha$-SMA, fibronectin, and vimentin when compared to the control group (Figure 3C-F). Notably, after $72 \mathrm{~h}$, MDA-ECM, and also positive control, induced, in a more prominent manner, a decrease in E-cadherin expression (Figure 3B), accompanied by an increase in the expression of the transcriptional repressor TWIST (Figure 3G). For these reasons, we decided to use the time of $72 \mathrm{~h}$ in this study. 
A

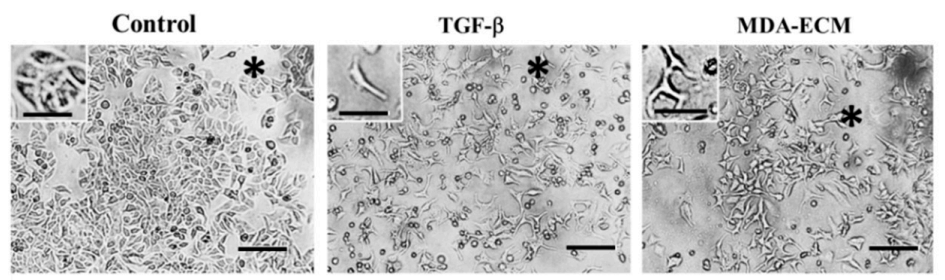

B

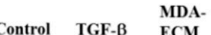

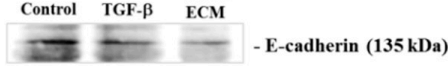
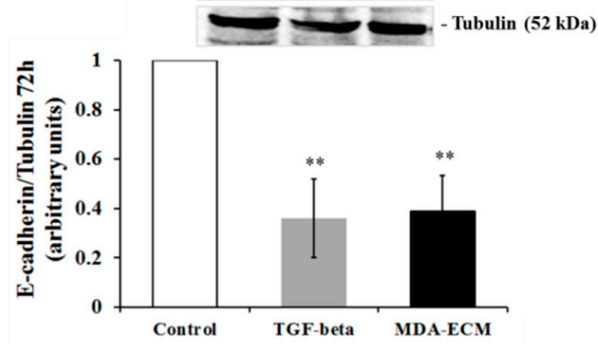

$\mathrm{C}$

D

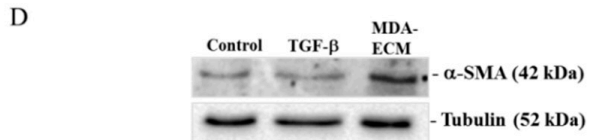

E
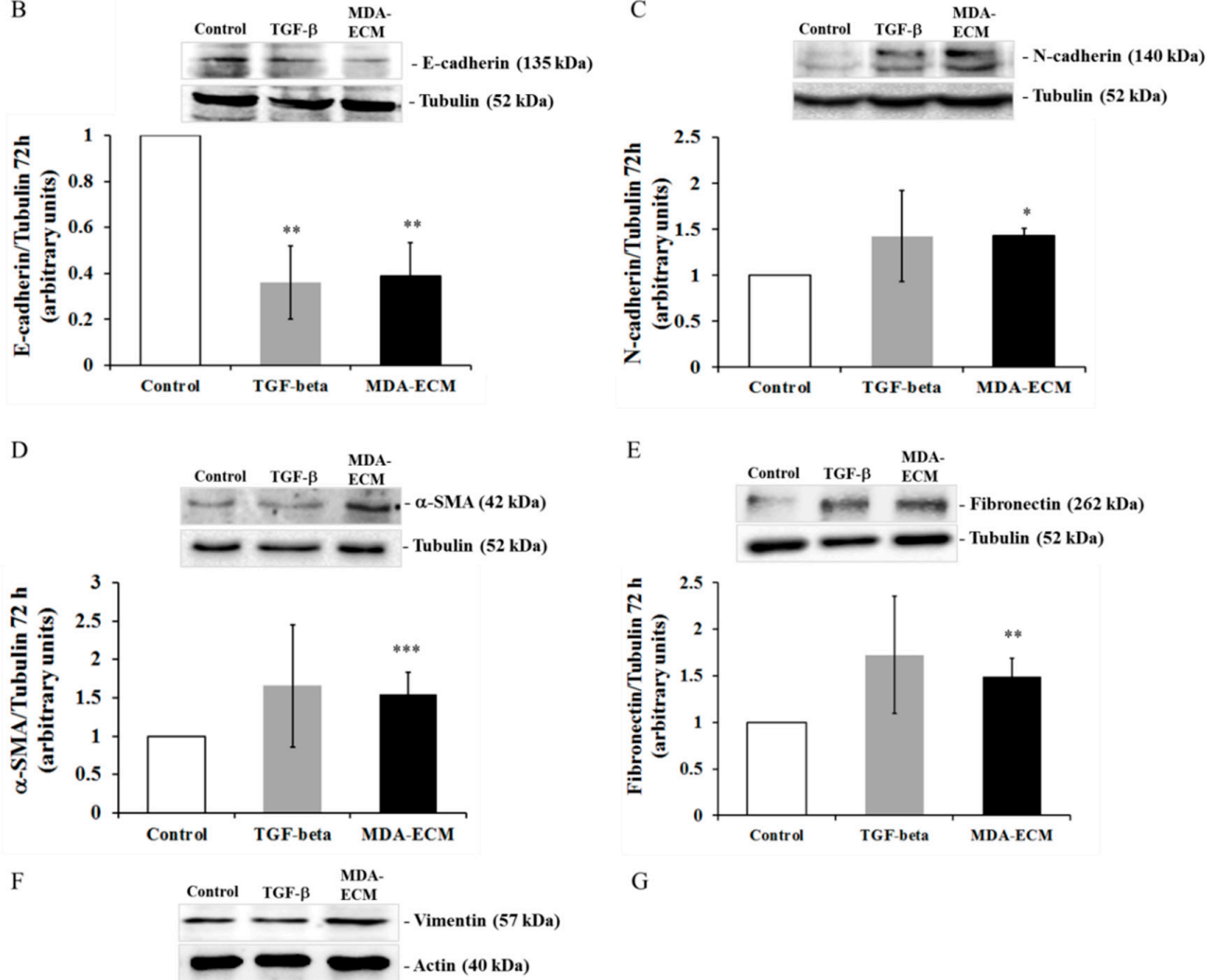

G
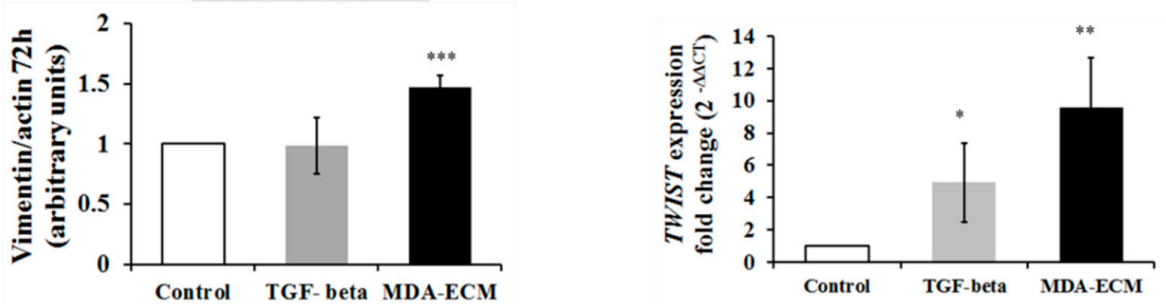

Figure 3. MDA-MB-231-derived ECM triggered morphological and phenotypical changes related to epithelial-mesenchymal transition (EMT) in MCF-7 cells after $72 \mathrm{~h}$. MCF-7 and MDA-MB-231 cells were cultured in standard conditions for $72 \mathrm{~h}$, and decellularized ECMs were obtained, as described in Methods. MCF-7 cells were cultured onto MDA-ECM or onto their own matrix with TGF- $\beta 1$ (10 ng/mL) for $72 \mathrm{~h}$. (A) Cell morphology was analyzed, and representative images were obtained at $40 \times$ magnification. A black asterisk indicates lost or remaining intercellular connections. Scale bar: $20 \mu \mathrm{m}$ (B-F) Lysates of MCF-7 cultured as described for $72 \mathrm{~h}$ were immunoblotted with anti-E-cadherin (B), anti-N-cadherin (C), anti- $\alpha$-SMA (D), anti-fibronectin (E), and anti-vimentin (F) antibodies. The results are shown as the mean fold increase relative to the control (MCF-ECM), and bars show the mean \pm SD calculated from 3 individual experiments $\left({ }^{*} p<0.05,{ }^{* *} p<0.01\right.$ and $\left.{ }^{* * *} p<0.001\right)$. (G) MCF-7 cells were cultured for $48 \mathrm{~h}$ on MCF-ECM with or without TGF- $\beta 1$ or MDA-ECM, and the expression of TWIST mRNA was analyzed. $\beta$-Actin was used as a housekeeping gene. The results are shown as the mean \pm SD calculated from 3 individual experiments $\left({ }^{*} p<0.05\right)$. 
ECM can anchor a variety of molecules, including TGF- $\beta$ [17], which can induce EMT changes in certain breast cancer cells [13]. Thus, we considered whether the TGF- $\beta$ produced by MDA-MB-231 cells could be, in part, present on MDA-ECM, regulating EMT changes observed in MCF-7 cells. MDA-MB-231 cells secreted more amounts of TGF- $\beta$ in the conditioned medium than MCF-7 cells [32,33]. To investigate the possibility that TGF- $\beta$ secreted by MDA-MB-231 cells change MCF-7 phenotype, cells were cultured for $72 \mathrm{~h}$ with the conditioned medium harvested from MDA-MB-231 cell cultures. We did not observe any decrease of E-cadherin expression in MCF-7 cells treated with the MDA-MB conditioned medium (Figure 4A). Furthermore, treatment with $15 \mu \mathrm{g} / \mathrm{mL}$ of an inhibitor of the TGF- $\beta$ type I receptor (SB431542) did not interfere with the effect of MDA-ECM on E-cadherin expression in MCF-7 cells (Figure 4B). Consistently, SB431542 inhibited the direct effect of TGF- $\beta 1$ on E-cadherin levels in MCF-7 cells (Figure 4B). The efficiency of the TGF- $\beta$ inhibitor has been tested (Figure S1A,B). These sets of data suggested that the MCF-7 cell-matrix contact with MDA-ECM could be contributing to the decrease in E-cadherin expression, favoring EMT in MCF-7 cells.
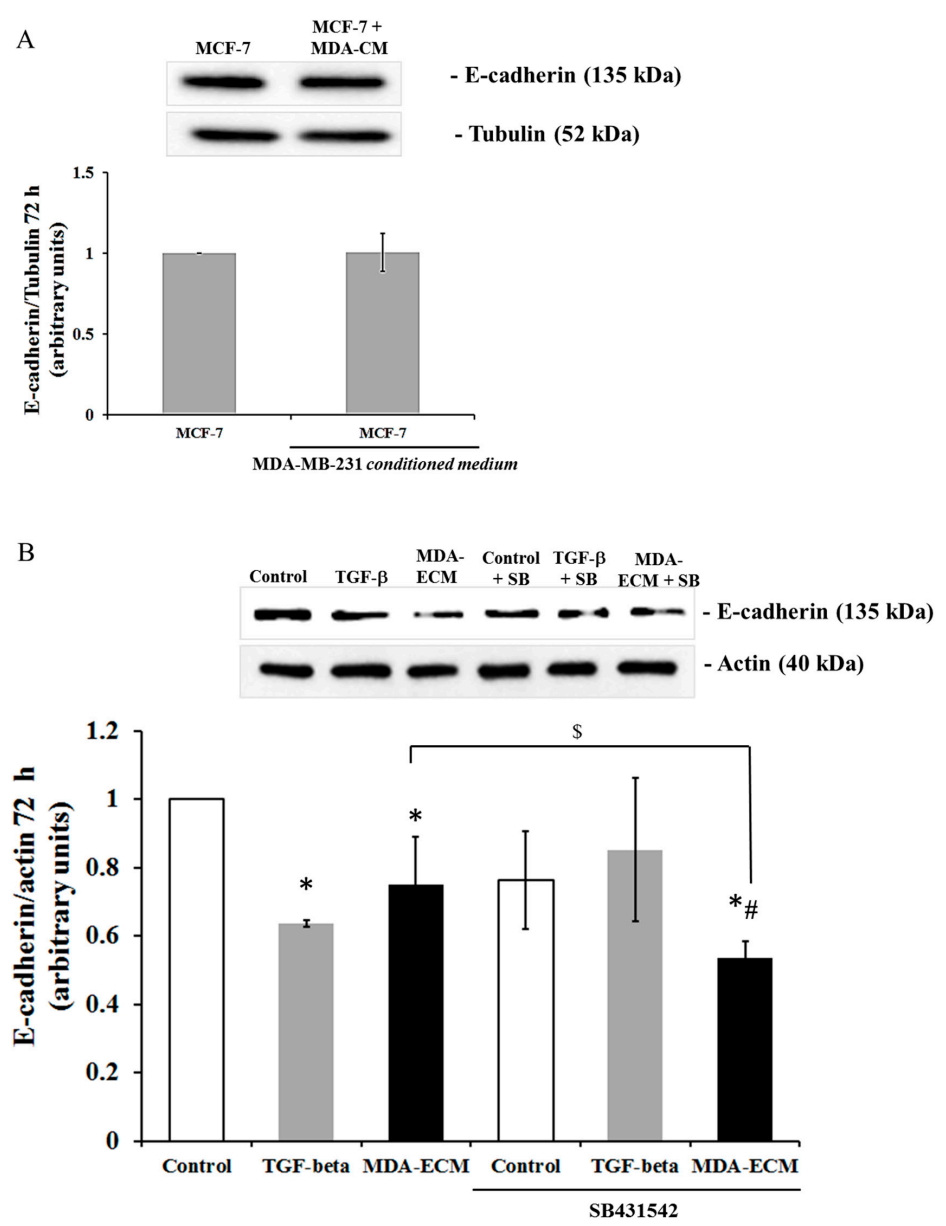

Figure 4. MDA-MB-231-derived ECM decreased E-cadherin expression in MCF-7 cells independent of TGF-beta receptor activation. MCF-7 and MDA-MB-231 cells were cultured in standard conditions for $72 \mathrm{~h}$, and decellularized ECMs were obtained, as described in the Methods. (A) MCF-7 were seeded on their own matrix for $72 \mathrm{~h}$ with or without conditioned medium from MDA-MB-231 cultures. Cell lysates were immunoblotted with anti-E-cadherin and anti-tubulin antibodies. (B) MCF-7 cells were seeded on decellularized MCF-ECM with or without TGF- $\beta 1$ or MDA-ECM in the presence or absence of the TGF- $\beta$ receptor inhibitor SB431542 $(15 \mu \mathrm{g} / \mathrm{mL})$ for $72 \mathrm{~h}$. Cell lysates were immunoblotted with anti-E-cadherin and anti-actin antibodies. The results are shown as the mean fold increase relative to the MCF-ECM (* $p<0.05)$; MCF-ECM treated with SB431542 (\# $p<0.05)$ and MDA-ECM without inhibitor $(\$ p<0.05)$ were calculated from 3 individual experiments. 


\subsection{Interaction with MDA-ECM Increased MCF-7 Cells Migratory Capacity}

Loss of cell-cell adhesion structures and polarity leads to increased motility and invasiveness of tumor epithelial cells [6,12,34]. MCF-7 cells are known to have a low capacity of migration in vitro [35]. Therefore, to evaluate the effect of MDA-ECM on MCF-7 migration, we incubated these cells onto their own matrix in the presence or absence of TGF- $\beta$ or onto MDA-ECM for $72 \mathrm{~h}$, and then these cells were added in transwell inserts. Using the FBS-enriched medium as a chemoattractant, MCF-7 cells were allowed to migrate for $72 \mathrm{~h}$. Figure 5 demonstrates that the previous treatment with TGF- $\beta$ or with MDA-ECM increased the migration of MCF-7 cells. However, MCF-7 cells that were previously seeded onto MDA-ECM had a most effective increase (4.2 fold increase), when compared with the positive control (1.4 fold increase).

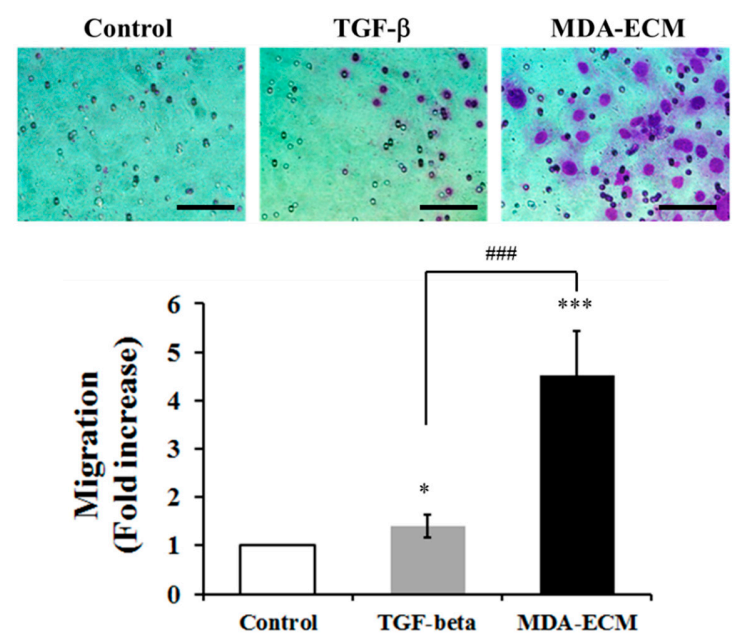

Figure 5. Effect of MDA-ECM on the migratory capacity of MCF-7 cells. MCF-7 and MDA-MB-231 cells were cultured in standard conditions for $72 \mathrm{~h}$, and decellularized ECMs were obtained, as described in the Methods. MCF-7 cells were cultured for $72 \mathrm{~h}$ on decellularized ECM derived from MDA-MB-231 or MCF-7 cells with or without TGF- $\beta 1$. After that, cells were trypsinized, seeded on Transwell chambers, and allowed to migrate toward FBS-enriched medium (10\%) for $72 \mathrm{~h}$. The number of migrated cells was counted, and the results are shown as the fold increase relative to the control MCF-ECM $\left({ }^{*} p<0.05\right.$ and $\left.{ }^{* * *} p<0.001\right)$ and the positive control TGF-beta (\#\#\# $\left.p<0.001\right)$ and presented as the mean \pm SD calculated from 3 individual experiments. Scale bar: $20 \mu \mathrm{m}$.

\subsection{Interaction with MDA-ECM Triggered Integrin and TGF- $\beta$ Signaling Pathways in MCF-7 Cells}

Alterations in ECM composition can influence the phenotype of different cell types present in the tumor stroma [18]. Integrin coordinates the interactions between cells and ECM, triggering adhesive signaling characterized by focal adhesion kinase (FAK) activation and the recruitment of the actin cytoskeleton; this is followed by a cascade of intracellular signals that are also involved in cell migration, proliferation, and survival, including PI3K/Akt and MAPK/ERK pathway activation [36,37].

We assessed through confocal microscopy the focal adhesion assembly in MCF-7 cultured onto the tumors-derived matrices, using double staining for F-actin and vinculin that appeared as yellow spots on cell borders (Figure 6A; white asterisks). The interaction with MDA-ECM, as well as the treatment with TGF- $\beta 1$, impaired focal adhesion formation in MCF-7 cells (Figure 6A,B). However, MCF-7 cells seeded onto MDA-ECM showed major alterations in the cytoskeleton dynamics, presenting stress fibers with lamellipodia and filopodia formation, very characteristics of a migratory profile (Figure 6A, lower panel). This phenotype contrasted with that of MCF-7 cells cultured on MCF-ECM, with or without TGF- $\beta 1$ that presented a more cortical distribution of F-actin (Figure 6A, upper and middle panels). In parallel, we also showed that MCF-7 cells seeded on MDA-ECM increased FAK ${ }^{\mathrm{Y} 397}$ phosphorylation (Figure 6C), phospho-ERK1/2 (Figure 6D), and phospho-AKT (S473) (Figure 6E), characterizing the involvement of integrin-associated signaling. 
Canonical and non-canonical TGF- $\beta$ receptor signaling pathways are reported to regulate EMT. The activation of FAK and of PI3K, and AKT pathways, can be also involved in non-canonical activation of the TGF- $\beta$ receptor [38]. The onset of the canonical TGF- $\beta$ receptor signaling comprises the phosphorylation of SMAD2 that, together with SMAD 3, triggers SMAD4 translocation to the nucleus [9]. When MCF-7 cells were seeded onto MDA-ECM, we observed, in parallel to integrin signaling activation, an increase in SMAD2 phosphorylation (S465-467) expression (Figure 6F) and increased SMAD4 expression in the cell nucleus (Figure 6G).

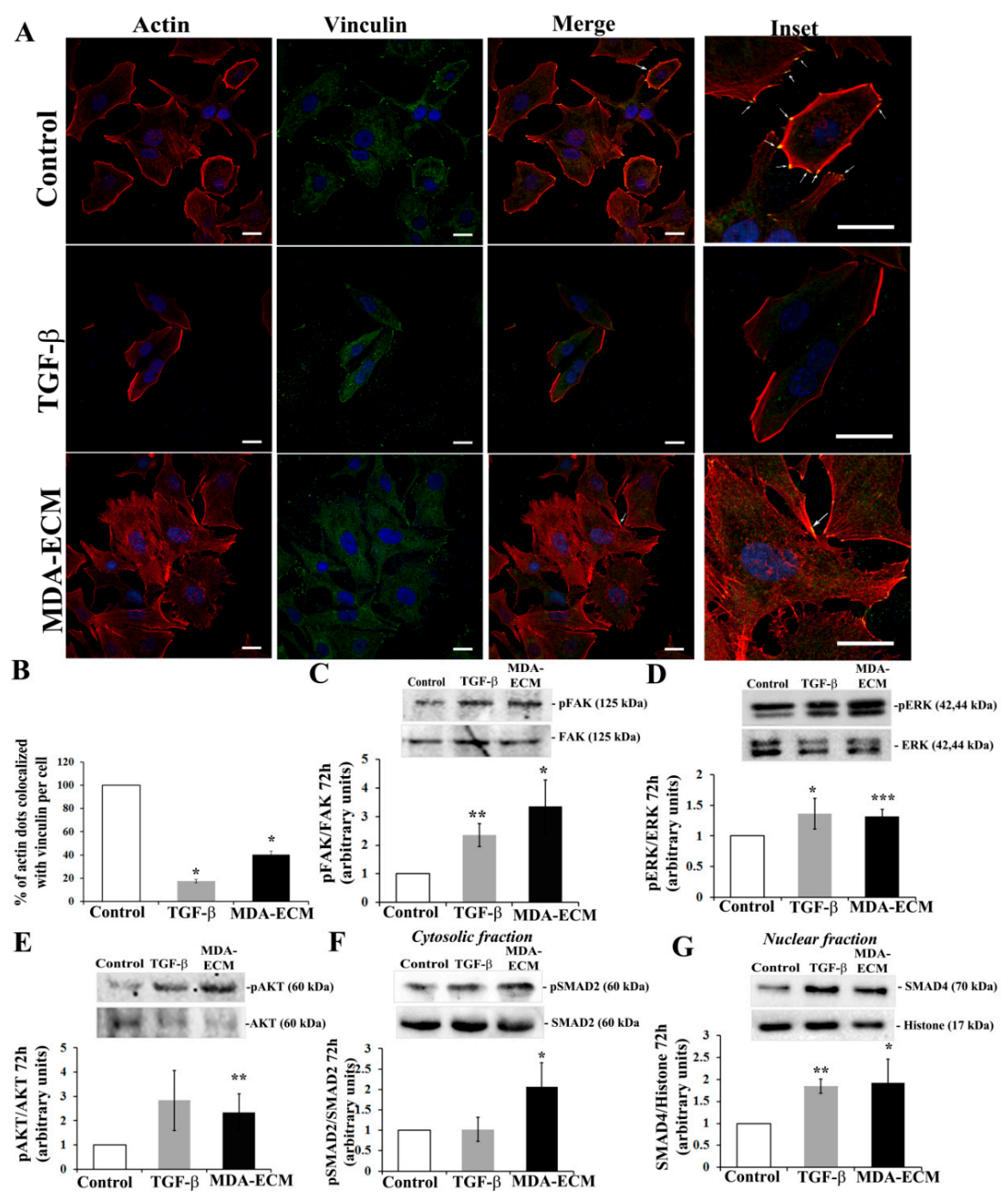

Figure 6. Interaction with MDA-ECM triggered integrin and TGF- $\beta$-associated signaling pathways in MCF-7 cells. (A) MCF-7 and MDA-MB-231 cells were cultured in standard conditions on coverslips for $72 \mathrm{~h}$, and decellularized ECMs were obtained, as described in Methods. For double staining of F-actin and vinculin (indicated by the white asterisks), cells were marked with rhodamine-conjugated phalloidin (red) and anti-vinculin antibody (green), and nuclei were stained with DAPI. Representative images were captured at $60 \times$ magnification. Focal adhesion assembly in control is highly visible in the section at high magnification (insets-right column). Scale bar: $20 \mu \mathrm{m}$. (B) Representative graph showing the percentage of colocalization of vinculin and actin in comparison to the control MCF-ECM. Cell lysates were immunoblotted with (C) anti-pFAK ${ }^{\mathrm{Ty} 397}$ and anti-FAK, (D) anti-pERK1/2 and anti-ERK1/2, (E) anti-pAKT ${ }^{\text {Ser473 }}$ and anti-AKT, (F) anti-pSMAD2 and anti-SMAD2, and (G) anti-SMAD 4 and anti-histone (H3) antibodies. The results are shown as the fold increase compared to the MCF-ECM group, calculated from 3 individual experiments $\left({ }^{*} p<0.05\right.$; ${ }^{* *} p<0.01$; $\left.{ }^{* *} p<0.001\right)$. 


\subsection{Involvement of $\alpha v \beta 3$ Integrin in the EMT of MCF-7 Cells Cultured on MDA-ECM}

Integrins are reported to have a critical role during the process of EMT through crosstalk with TGF- $\beta$ receptors $[4,8,12,19,39]$. To evaluate the role of integrins in the activation of TGF- $\beta R$ signaling activation, the experiments were performed in the presence of a synthetic tripeptide RGD (Arg-Gly-Asp) that blocks $\alpha \mathrm{v}$ integrin activation [40]. Figure 7 shows that the RGD peptide impaired the decrease in E-cadherin levels (Figure 7A) of cells cultured onto MDA-ECM. Supporting the data, the immunofluorescence analysis showed the presence of E-cadherin in the intercellular junctions in MCF-7 cells cultured on MDA-ECM treated with RGD, contrasting with cells not treated with the peptide or stimulated with TGF- $\beta 1$ (Figure S2A,B). In addition, RGD treatment inhibited SMAD2 phosphorylation only in MCF-7 cells cultured on MDA-ECM and not in MCF-ECM groups (Figure 7C).

A

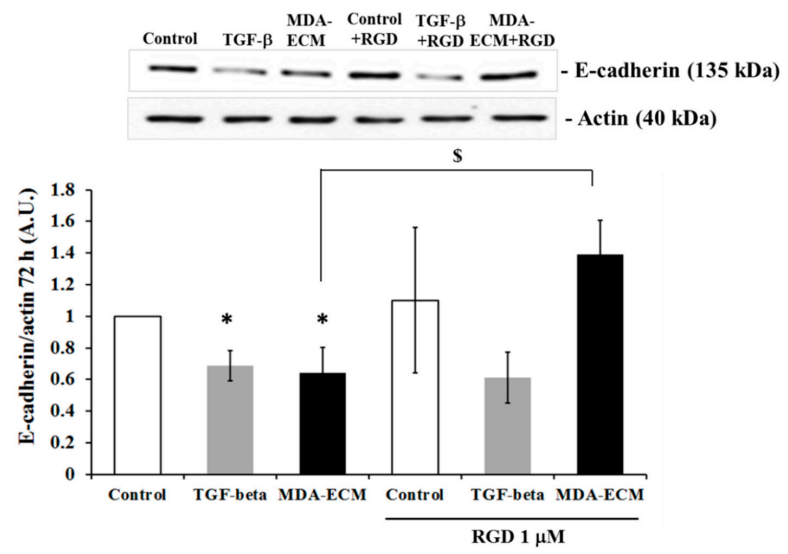

B

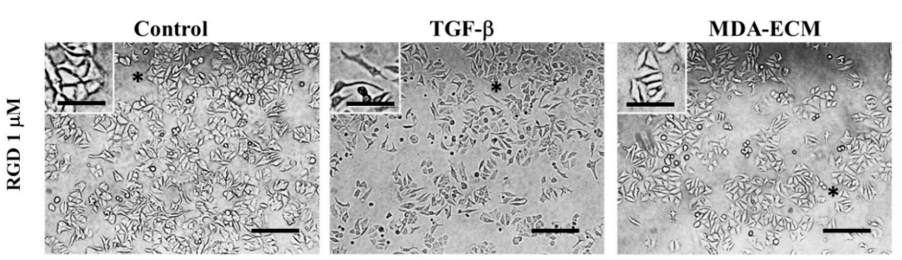

$\mathrm{C}$

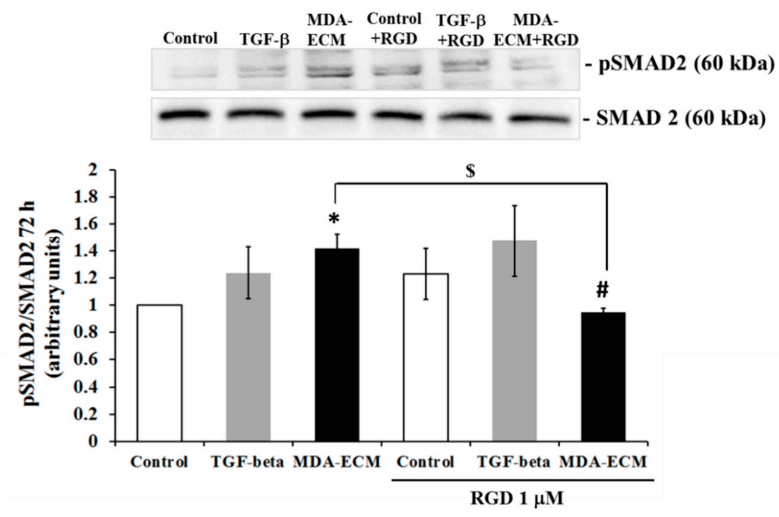

Figure 7. Integrin signaling modulated the effects of MDA-ECM on E-cadherin-mediated adhesion of MCF-7 cells. MCF-ECM and MDA-ECM were obtained, as described in the Methods section. MCF-7 cells were cultured on their own ECM with or without TGF- $\beta 1$ or on MDA-ECM and treated with Arg-Gly-Asp (RGD) for $72 \mathrm{~h}(1 \mu \mathrm{M})$. Cell lysates were immunoblotted with (A) anti-E-cadherin and (C) anti-p-SMAD2 antibodies. (B) Representative images of MCF-7 cell cultures of each experimental group, treated or not with RGD $(1 \mu \mathrm{M})$, at $40 \times$ magnification. A black asterisk indicates lost or remaining intercellular connections. Scale bar: $20 \mu \mathrm{m}$. The results are shown as the mean fold increase relative to controls: MCF-ECM ( $*<<0.05)$, MCF-ECM + RGD (\# $p<0.05)$, and MDA-ECM $(\$ p<0.05)$, calculated from 3 individual experiments. 
The involvement of $\alpha \mathrm{v}$ subfamily of integrins has been often associated with EMT in human breast cancer cells [12,41]. To evaluate the involvement of $\alpha \mathrm{v}$ integrins as mediators of EMT in our experimental model, MCF-7 cells cultured on their own matrix, with or without TGF- $\beta 1$ and MDA-ECM, were treated with Kistrin, an RGD-disintegrin that selectively binds to and blocks many functions of $\alpha \mathrm{v} \beta 3$ integrin [40,42]. The treatment with Kistrin impaired the effect of MDA-ECM on MCF-7 cells, maintaining high levels of E-cadherin expression (Figure 8A) and supporting cell-cell contacts with tight intercellular connections, indicated by the black asterisk (Figure 8B). In contrast, the effect of TGF- $\beta 1$ in decreasing E-cadherin expression and changing MCF-7 cells' morphology was not altered in cells treated with Kistrin (Figure 8A,B). Importantly, blocking $\alpha \mathrm{v} \beta 3$ integrin with Kistrin significantly decreased SMAD2 phosphorylation only in MCF-7 cells cultured on MDA-ECM, but not in control cells treated or not with TGF- $\beta 1$ (Figure $8 \mathrm{C}$ ). These data indicated that MDA-ECM-induced EMT-related changes in MCF-7 cells might be driven by $\alpha v \beta 3$ integrin-mediated interactions.

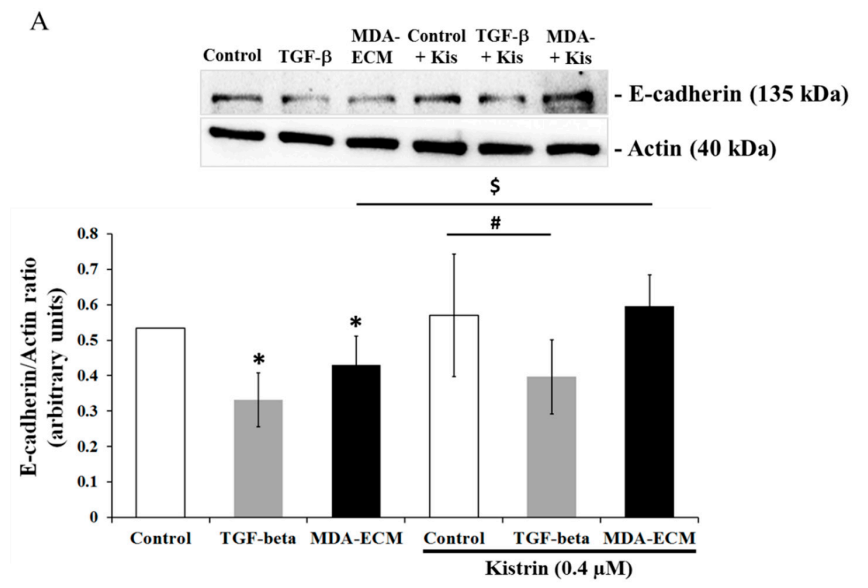

B

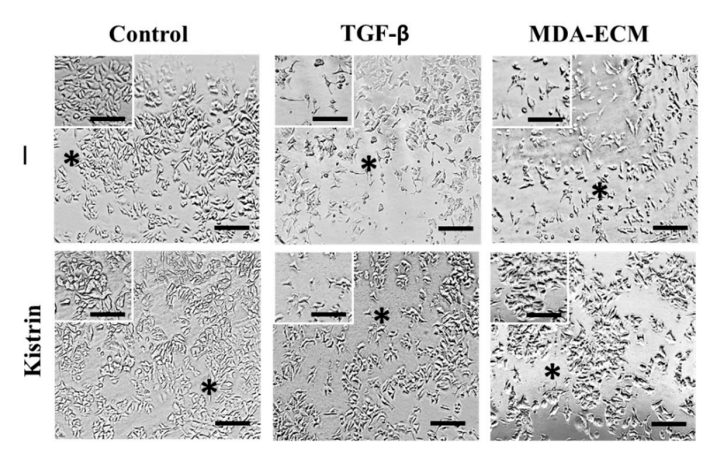

$\mathrm{C}$

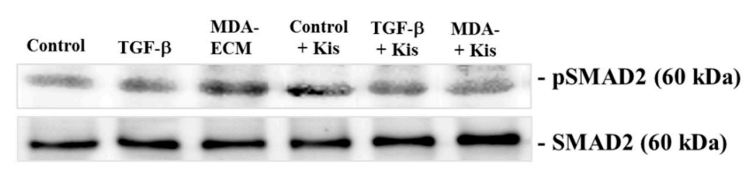

$\$$

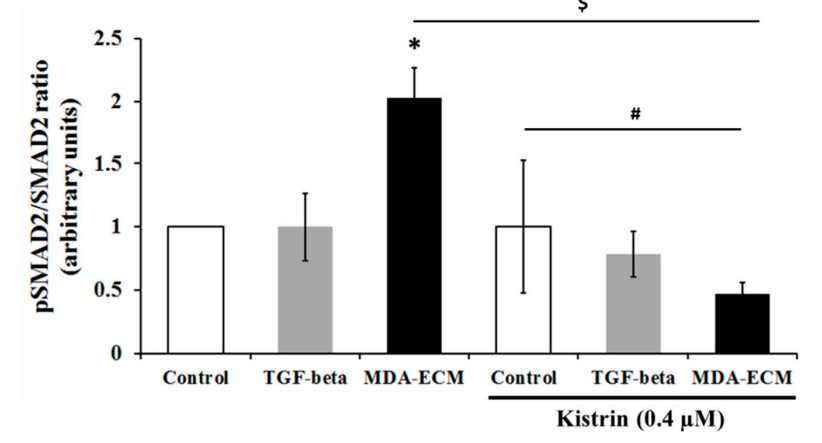

Figure 8. Involvement of integrin $\alpha \mathrm{v} \beta 3$ in EMT of MCF-7 cells cultured on MDA-ECM. MCF-ECM and 
MDA-ECM were obtained, as described in the Methods section. MCF-7 cells were cultured on their own ECM with or without TGF- $\beta 1$ or on MDA-ECM and treated with Kistrin for $72 \mathrm{~h}(0.4 \mu \mathrm{M})$. Cell lysates were immunoblotted with (A) anti-E-cadherin and (C) anti-p-SMAD2 antibodies. The results are shown as the mean fold increase relative to controls: MCF-ECM $\left({ }^{*} p<0.05\right), \mathrm{MCF}-\mathrm{ECM}+\mathrm{Kistrin}$ (\# $p<0.05)$, and MDA-ECM (\$ $p<0.05)$, calculated from 3 individual experiments. (B) Representative images of MCF-7 cell cultures of each experimental group, treated or not with Kistrin $(0.4 \mu \mathrm{M})$, at $10 \times$ magnification. A black asterisk indicates lost or remaining intercellular connections. Scale bar: $20 \mu \mathrm{m}$.

\section{Discussion}

In the tumor microenvironment, ECM produced by different tumor cell types varies along cancer progression stages [43]. Evidence has shown that ECM proteins modulate the behavior of cells in the tumor niche, including the ECM produced by tumor cells themselves, providing critical signals that can contribute to cancer development [25]. Despite the complex structure of tumor-produced ECMs, most studies on the role of matrices in cancer have been performed using single ECM proteins or artificial matrices $[13,44,45]$. Here, we used a natural 3D matrix produced by highly metastatic breast cancer cells (MDA-MB-231) to investigate how it would affect the phenotype of non-metastatic MCF-7 cells, focusing on its capacity to induce EMT.

The transition from an epithelial to a mesenchymal phenotype is a key mechanism in cancer progression whereby tumor cells down-regulate epithelial markers and increase mesenchymal markers, becoming more migratory and acquiring a more aggressive behavior. These changes usually correlate to a higher invasive potential, increased metastasis, and poor patient outcome [46]. Different studies have demonstrated that isolated matrix proteins can influence EMT in some tumors, particularly in breast cancer $[9,13,19,23,24,27,39,47-49]$.

Intratumor heterogeneity consists of a major challenge for designing effective therapies, and breast cancers are usually highly heterogeneous, including tumor cells at different stages of differentiation [1,50]. For this reason, one expects that the composition of ECM produced by each cell type may differ and influence the phenotype of neighboring cells present in the tumor mass. We showed that the interaction with the extracellular matrix produced by high metastatic breast cancer cells, MDA-MB-231, is able to induce EMT in MCF-7 cells, an epithelial-type breast cancer cell, increasing mesenchymal marker expression, modifying cell phenotype, and stimulating cell migration. These changes were detected when MCF-7 cells were cultured on MDA-ECM, which, in a comparative analysis, showed a distinct matrix protein composition. The ECM produced by MDA-MB-231 cells presented higher amounts of tenascin- $\mathrm{C}$ and laminin and a less effective increase in osteopontin and vitronectin and lower amounts of fibronectin when compared to MCF-ECM.

The tenascin-C expression is normally sparse in healthy human cells but is rapidly induced in many tissues in response to pathological stress [51]. Up-regulation of tenascin-C correlates with situations of tissue repair, and increased tenascin- $C$ protein levels have been detected in human cancers and are associated with a poor prognosis, higher aggressiveness, and malignancy [52,53]. Soluble tenascin- $C$ has been shown to enhance migration and loss of intercellular adhesion in breast cancer cells [13]. Laminin has been described as a potent adhesive and migratory substrate for metastatic breast tumor cells in vitro, and its higher expression correlates with tumor grade and metastatic potential in vivo [4]. Laminin has also been shown to increase the migration of MCF-7 and MDA-MB-231 cells through a mechanism involving integrin modulation [19]. Osteopontin, whose expression was also augmented in MDA-ECM, has been associated with a poor prognosis in patients with breast cancer [20,54] and with higher metastatic potential in rodent models [55]. Finally, vitronectin, which, along with osteopontin, is a potent ligand of $\alpha \mathrm{v} \beta 3$ integrin, seems to modulate cancer cell adhesion, migration, and angiogenesis [56]. The presence of these proteins on MDA-ECM is consistent with the increased metastatic potential of MDA-MB-231 cells. Differences in MDA-ECM composition might be responsible for inducing EMT in MCF-7 cells, which assumed morphologic, molecular, and functional profiles typical of a mesenchymal phenotype. After the interaction of those epithelial 
breast cancer cells with MDA-ECM for $72 \mathrm{~h}$, we observed a decrease in E-cadherin expression and an increase in $\mathrm{N}$-cadherin and other mesenchymal markers, such as $\alpha$-SMA, vimentin, fibronectin, and TWIST. These molecular changes were accompanied by loss of cell-cell contacts and increasing migratory capacity of MCF-7 cells. Noteworthy, after $72 \mathrm{~h}$ incubation of MCF-7 cells with TGF- $\beta$ (used as positive control), compared with MDA-ECM, we observed a less evident effect on EMT markers, which could be explained because TGF- $\beta$ effects peaked in earlier times and might decrease afterward (Figures 2 and 3).

The extracellular matrix can regulate the availability and activity of many carcinogenic mediators, including TGF- $\beta$, through controlled sequestration, presentation, and release [19]. Since the MDA-MB-231 cells could be releasing TGF- $\beta$ in culture medium $[29,30]$, we argued whether this secreted TGF- $\beta$ might change the MCF-7 phenotype. We demonstrated that TGF- $\beta$, if present in the conditioned medium of MDA-MB-231 cell cultures, was not critical for the induction of EMT in our model. Furthermore, blocking the TGF- $\beta$ receptor in MCF-7 cells did not modify the EMT induced by MDA-ECM, but impaired the TGF- $\beta$ effects on EMT protein markers and on changes of epithelial morphology (Figure 4 and Figure S1A,B). Although we could not completely discard the presence of TGF- $\beta$ and other soluble factors anchored to MDA-ECM, our data strongly evidenced that the direct contact with MDA-ECM could prime MCF-7 cells triggering an EMT more efficiently than in the presence of TGF- $\beta$ alone.

It has been reported that integrin-mediated cell-matrix interactions can modulate tumor progression, including EMT $[4,12,19,39,57]$. We showed that MCF-7 cells cultured on MDA-ECM assumed a more activated and migratory profile, with profound changes in cytoskeleton dynamics. These alterations in cell morphology were accompanied by the activation of integrin signaling pathways, with an increase in the phosphorylation of FAK, AKT, and ERK in MCF-7 cells cultured on MDA-ECM.

Activated FAK acts as a scaffold protein with binding sites for several classes of signaling molecules, including PI3K/AKT and MAPK/ERK, that regulate cell migration and survival and are involved in the non-canonical TGF- $\beta$ signaling pathway $[8,58,59]$. In addition, recent studies have shown that AKT and ERK are involved in EMT, participating in the crosstalk between the integrin and TGF- $\beta$ receptor pathways [8,9,60-62]. Increased amounts of type I collagen correlate with integrins, switching to a high-affinity ligand-binding state, increasing FAK- and ILK-signaling activity, and promoting EMT in tumor pancreatic cells, for example [63]. Our data showed that MDA-ECM induced an increase in integrin signaling activation parallel with an increase in SMAD2 phosphorylation and subsequent translocation of SMAD4 to the nucleus in MCF-7 cells, suggesting crosstalk between integrin and TGF- $\beta$ receptor signaling pathways. These effects of MDA-ECM were more evident in MCF-7 cells after $72 \mathrm{~h}$ in contact with the matrix, occurring later than the direct effects of TGF- $\beta$, which were more prominent at early times (Figure 2). This is rather interesting that EMT could be further improved in epithelial tumor cells after their contact with the ECM produced by a higher metastatic cell present in the same tumor mass.

To investigate the role of integrins in the effects induced by MDA-ECM, the cells were treated with RGD peptide, an unspecific ligand of integrins, or with Kistrin, a selective ligand of $\alpha \mathrm{v} \beta 3$ integrin [51,52], both able to bind and block many integrin functions [40]. The treatment of MCF-7 cells seeded on MDA-ECM with Kistrin or RGD preserved cell-matrix and cell-cell contacts, but impaired the decrease of E-cadherin expression and SMAD2 phosphorylation, revealing transactivation between integrins and TGF- $\beta$ receptor to drive EMT. Interestingly, it is already known that integrin $\alpha \mathrm{v} \beta 3$ is expressed in epithelial cells in cancer tissues and acts as a driver of cancer progression, stemness, and metastasis. So, this integrin possibly, in conjunction with growth factor receptors, can regulate proliferation and migration of cancer cells influenced by tenascin-C protein [64-66]. Noteworthy, tenascin- $\mathrm{C}$ is the most expressed extracellular matrix in MDA-ECM. Therefore, tenascin-C expression accompanied with vitronectin and laminin in MDA-ECM, which can bind to $\alpha \mathrm{v} \beta 3$, could have a crucial role for triggering EMT in MCF-7 cells. 
In line with these observations, some studies have correlated the different expression of extracellular matrix proteins and its stiffness to aberrant activation of the TGF- $\beta$ pathway, accompanied by an expression of determined integrins, with enhancing cancer cell stemness and invasion [67-69]. In addition, tumor-initiating cells are more resistant to detachment-induced anoikis and exhibit phenotypic plasticity to move between epithelial to mesenchymal states $[69,70]$. Tumor-initiating cells are the driver for drug resistance, cancer relapses, and metastasis, which remains to occur in some cases of breast cancer [69-71]. Taken together, this evidence suggests a tight association among the EMT phenotype induced by MDA-MB-231-derived extracellular matrix, through $\alpha \mathrm{v} \beta 3$ integrin activity and tumor-initiating cells, but further investigation is required in future studies.

\section{Material and Methods}

\subsection{Reagents}

Culture reagents-bovine serum albumin (BSA), penicillin, streptomycin, trypsin, Dulbecco's Modified Eagle Medium (DMEM); Arg-Gly-Asp (RGD); protease inhibitors, phenylmethylsulfonyl fluoride (PMSF), leupeptin, and ribonuclease A (RNase A); trypan blue and specific inhibitor of transforming growth factor-beta superfamily type, SB431542 (Sigma-Aldrich, St. Louis, MO, USA, \#S4317), was diluted in DMSO to obtain a stock concentration of $1000 \mu \mathrm{M} / \mathrm{mL}$. Recombinant human TGF-beta was from Peprotech (Ribeirão Preto, SP, Brazil). Fetal bovine serum (FBS) was purchased from Cultilab (Campinas, SP, Brazil). BCA protein assay kit was purchased from Thermo Scientific. TRITC-labeled phalloidin was obtained from Sigma-Aldrich (St. Louis, MO, USA), DAPI ProLong ${ }^{\circledR}$ was obtained from Invitrogen (Carlsbad, CA, USA), and Alexa Fluor 555 and 488 were obtained from Invitrogen, Paisley, UK. PVDF membranes and Rainbow ${ }^{\mathrm{TM}}$ molecular weight markers were from GE Healthcare (San Francisco, CA, USA), and the ECL system (SuperSignal West Pico chemiluminescent substrate kit) was from Pierce Biotechnology (Rockford, IL, USA). High capacity cDNA reverse transcription kit was purchased from Applied Biosystems. The RNeasy mini kit and SYBR-green were obtained from Qiagen. Primers for TWIST (Forward 5'-GGCACCATCCTCACACCTCT-3'; reverse $3^{\prime}$-TGGCTGATTGGCACGACCT- $5^{\prime}$ ) and $\beta$-actin (Forward 5'-TACAATGAGCTGCGTGTGG- ${ }^{\prime}$; reverse $3^{\prime}$-TAGCACAGCCTGGATAGCAA-5') were purchased from IDT technologies. The panoptic staining kit was from LB Laborclin (Pinhais, PR, Brazil). Kistrin (Kr; Lot 44H4073), isolated from Agkistrondon rhodostome venom, was purchased from Sigma Chemical Co. (St. Louis, MO, USA).

\subsection{Antibodies}

Primary antibodies: rabbit polyclonal anti-p-FAK ${ }^{\mathrm{Ty} 397}$ and anti-tenascin-C (Invitrogen, Carlsbad, CA, USA); mouse monoclonal anti-osteopontin, anti- $\alpha$-SMA, goat monoclonal anti-Akt1, and rabbit polyclonal anti-vitronectin (Santa Cruz Biotech., Santa Cruz, CA, USA); rabbit polyclonal anti-fibronectin (Dako, Denmark, SC, USA); rabbit monoclonal anti-FAK (Abcam, Cambridge, MA, USA); rabbit polyclonal anti-laminin, mouse monoclonal anti- $\alpha$-tubulin, and anti-vinculin (Sigma-Aldrich Co., St. Louis, MO, USA); rabbit monoclonal anti-E-cadherin, anti-SMAD2, anti-p-ERK1/2 ${ }^{\mathrm{Thr} 202 / 204}$, anti-p-SMAD2 ${ }^{\mathrm{Ser} 465 / 467}$, and polyclonal anti-actin, anti-ERK 1/2, anti-SMAD4, and anti-N-cadherin (Cell Signaling Technol., Danvers, MA, USA); mouse monoclonal anti-p-AktSer473, anti-actin, and rabbit monoclonal anti-histone (H3) (Millipore, Billerica, MA, USA). Secondary biotin-conjugated antibodies against rabbit IgG, mouse IgG, and goat IgG (Cell Signaling Technol. Danvers, MA, USA); Streptavidin-conjugated FITC and streptavidin-conjugated horseradish peroxidase (Carlsbad, CA, USA).

\subsection{Cell Cultures}

Human breast cancer cell lines (MCF-7 and MDA-MB-231) were a gift from Dr. V. Morandi (UERJ, RJ, Brazil) and certified (STR) by DNA Diagnostic Laboratory (UERJ, RJ, Brazil). MCF-7 and MDA-MB-231 cells were routinely maintained in DMEM supplemented with $10 \% \mathrm{FBS}, \mathrm{NaHCO}_{3}$ 
$(3.7 \mathrm{~g} / \mathrm{L})$, HEPES $(5.2 \mathrm{~g} / \mathrm{L})$, penicillin $(0.5 \mathrm{U} / \mathrm{mL})$, and streptomycin $(0.5 \mathrm{mg} / \mathrm{mL})$ and incubated at $37^{\circ} \mathrm{C}$ in a humidified atmosphere of $5 \% \mathrm{CO}_{2}$. For experiments, MCF-7 and MDA-MB-231 cells were grown to confluence and then detached with trypsin $(0.1 \%) /$ EDTA $(0.01 \%)$. To generate conditioned medium, MDA-MB-231 cells were grown in the same medium described above to $90-100 \%$ confluence $\left(4 \times 10^{6}\right.$ cells $)$ in $75 \mathrm{~cm}^{2}$ culture flasks for $72 \mathrm{~h}$.

\subsection{Isolation of Immobilized Cell-Derived Matrices}

Freshly deposited ECM produced by MCF-7 (MCF-ECM) or MDA-MB-231 (MDA-ECM) was obtained, as previously described [26]. Briefly, cells were seeded onto plastic 6-, 24-, or 96-well plates and grown for $72 \mathrm{~h}$. Monolayers were disrupted with cold lysis extraction buffer $(2.7 \mathrm{mM} \mathrm{KCl}, 1.4 \mathrm{mM}$ $\mathrm{KH}_{2} \mathrm{PO}_{4}, 68.3 \mathrm{mM} \mathrm{NaCl}, 8 \mathrm{mM} \mathrm{Na}_{2} \mathrm{HPO}_{4}, 1 \mathrm{mM} \mathrm{MgCl} 2,1 \mathrm{mM} \mathrm{CaCl}, 0.1 \%$ Triton X-100, and $100 \mathrm{mM}$ $\mathrm{NH}_{4} \mathrm{OH}$ ) for 3-5 min until the cells appearing floating in the medium. Cell debris was washed twice with cold PBS- $\mathrm{Ca}^{2+}$, and the wells were saturated with $0.1 \% \mathrm{BSA} / \mathrm{PBS}-\mathrm{Ca}^{2+}$ for $1 \mathrm{~h}$ at $37^{\circ} \mathrm{C}$ immediately before use. Analysis under the light microscope showed that after this procedure, only the cell-derived ECM remained on the bottom of the wells, as described earlier [39].

\subsection{Stimulation of MCF-7 Cells to Epithelial-Mesenchymal Transition (EMT)}

MCF-7 cell suspension in DMEM 5\% FBS medium $\left(2 \times 10^{5}\right.$ cells/well $)$ was seeded onto freshly immobilized extracellular matrices derived from MCF-7 and MDA-MB-231 cells. MCF-7 cells seeded onto their own matrix and stimulated with TGF- $\beta 1(10 \mathrm{ng} / \mathrm{mL})$ were used, respectively, as control and positive controls for EMT.

\subsection{Analysis of ECM Composition by Indirect ELISA}

The composition of deposited matrices from different cell types was analyzed by indirect ELISA, as previously described [39]. Absorbance was measured at $490 \mathrm{~nm}$ in an automatic ELISA microplate reader (Thermo Scientific, Waltham, MA, USA).

\subsection{Immunofluorescence of E-cadherin and Confocal Microscopy}

Immobilized MCF-ECM and MDA-ECM were obtained on sterile glass coverslips. MCF-7 cells $\left(7 \times 10^{4}\right.$ cells/well $)$ were then cultured onto these matrices for $72 \mathrm{~h}$. For the inhibition of integrin activation, MCF-7 cells $\left(7 \times 10^{4}\right.$ cells/well) were treated with $1 \mu$ M RGD peptide (Arg-Gly-Asp) for $72 \mathrm{~h}$. After $72 \mathrm{~h}$, cells were fixed with $4 \%$ paraformaldehyde in sucrose/PBS solution for $20 \mathrm{~min}$ at room temperature, permeabilized with Triton X-100 (0.1\%)/PBS for $5 \mathrm{~min}$, and blocked with $5 \%$ BSA for $30 \mathrm{~min}$. For the detection of E-cadherin by immunofluorescence, the slides were incubated with rabbit monoclonal anti-E-cadherin (1:400) overnight at $4{ }^{\circ} \mathrm{C}$, washed and then incubated with the appropriate secondary antibody for $1 \mathrm{~h}$, followed by incubation with Alexa Fluor 555 at $4{ }^{\circ} \mathrm{C}$ for $1 \mathrm{~h}$. Finally, slides were mounted using ProLong Gold antifade reagent with 4,6-diamidino-2-phenylindole (DAPI) for nuclear staining. Coverslips were examined under an Olympus BX40 microscope equipped for epifluorescence at $60 \times$ magnification. Fluorescence intensity was measured at intercellular junctions on the surface of MCF-7 cells (white asterisks). The result showed the mean \pm SD of the relative fluorescence intensity, measured on Icy bioimage analysis version 1.9.5.1 and Excel.

For confocal images, MCF-7 cells were labeled with TRITC-phalloidin (1:400) overnight at $4{ }^{\circ} \mathrm{C}$. Then, the sections were blocked with 5\% BSA for $30 \mathrm{~min}$ and incubated with mouse monoclonal anti-vinculin (1:200) overnight at $4{ }^{\circ} \mathrm{C}$. Coverslips were mounted and examined under an Olympus FV1000 Inverted Confocal IX81 at 60× magnification. Vinculin colocalized with actin (yellow points-white asterisks) was quantified by counting five random fields at the $60 \times$ magnification, for each treatment condition. The result showed the mean \pm SD of the number colocalized actin/vinculin per cell in percentage. Vinculin and actin colocalization were measured on Icy bioimage analysis version 1.9.5.1 and Excel. 


\subsection{Migration Assay}

MCF-7 $\left(2 \times 10^{5}\right.$ cells/well) cells incubated on different cell-derived matrices for $72 \mathrm{~h}$ were harvested and counted in a hemocytometer after staining with trypan blue. A total of $7 \times 10^{4}$ cells/well were added onto the upper membrane of each insert of Transwell ${ }^{\circledR}$ permeable supports (8- $\mu \mathrm{m}$ pore size filter membranes; Becton Dickinson) assembled in a 24-well plate (Falcon) and allowed to migrate for $72 \mathrm{~h}$ at $37^{\circ} \mathrm{C}$ and $5 \% \mathrm{CO}_{2}$. Then, non-migrating MCF-7 cells were removed with cotton swabs, while migrating cells on the lower surface of filters were fixed and stained with a panoptic kit for counting. Migrating cells were quantified as the number of cells that migrated through the insert, counted in 10 fields in an inverted microscope (Olympus IX71) at 40× magnification.

\subsection{Nuclear Extract}

MCF-7 cells $\left(2 \times 10^{5}\right.$ cells/well $)$ were seeded for $72 \mathrm{~h}$ on MDA-ECM or their own matrices. Then, cells were lysed in ice-cold buffer A (10 mM HEPES, pH 7.9, $10 \mathrm{mM} \mathrm{KCl}, 0.1 \mathrm{M}$ EDTA, $0.1 \mathrm{M}$, EGTA, $1 \mathrm{mM}$ DTT, and $0.5 \mathrm{mM} \mathrm{PMSF})$, and then Nonidet P-40 was added to a final concentration of $0.5 \%(v / v)$. Nuclei were collected by centrifugation $\left(1810 \times g\right.$ for $5 \mathrm{~min}$ at $\left.4{ }^{\circ} \mathrm{C}\right)$. The nuclear pellet was suspended in ice-cold buffer C (20 mM HEPES, pH 7.9, $400 \mathrm{mM} \mathrm{NaCl}, 1$ mM EDTA, 1 mM EGTA, 1 mM DTT, $1 \mathrm{mM}$ PMSF, $1 \mu \mathrm{g} / \mathrm{mL}$ pepstatin, $1 \mu \mathrm{g} / \mathrm{mL}$ leupeptin, and 20\% (v/v) glycerol) and incubated for $30 \mathrm{~min}$. Nuclear proteins were collected in the supernatant after centrifugation $\left(12,000 \times g\right.$ for $10 \mathrm{~min}$ at $\left.4{ }^{\circ} \mathrm{C}\right)$; then, the nuclear extracts were denatured in sample buffer $(50 \mathrm{mM}$ Tris- $\mathrm{HCl}, \mathrm{pH} 6.8,1 \% \mathrm{SDS}, 5 \%$ 2-ME, $10 \%$ glycerol, and $0.001 \%$ bromophenol blue) and assayed in SDS-PAGE.

\subsection{SDS-PAGE and Western Blot}

MCF-7 cells $\left(2 \times 10^{5}\right)$ were seeded for $72 \mathrm{~h}$ on MDA-ECM or MCF-7-ECM. To block TGF- $\beta$ RI signaling, cells were incubated for $72 \mathrm{~h}$ with $15 \mu \mathrm{g} / \mathrm{mL}$ SB431542, a potent and selective inhibitor of TGF- $\beta$ superfamily type 1 activin receptor-like kinase (ALK) receptors. To inhibit integrin activation, MCF-7 cells $\left(2 \times 10^{5}\right.$ cells/well $)$ were seeded on MCF-ECM and MDA-ECM, and after cell adhesion, RGD peptide $(1 \mu \mathrm{M})$ or Kistrin disintegrin $(0.4 \mu \mathrm{M})$ was added to cultures, which were then incubated in the presence or absence of TGF- $\beta 1$ for $72 \mathrm{~h}$. Then, MCF-7 cells were suspended in lysis buffer (50 mM Tris- $\mathrm{HCl}, \mathrm{pH} 7.4,150 \mathrm{mM} \mathrm{NaCl}, 1.5 \mathrm{mM} \mathrm{MgCl}_{2}, 1.5 \mathrm{mM}$ EDTA, Triton X-100 (1\%, v/v), glycerol $(10 \%, v / v)$, and the following protease inhibitors: $1 \mathrm{mM}$ phenylmethylsulfonyl fluoride (PMSF), $1 \mathrm{mM}$ benzamidine, and $1 \mu \mathrm{M}$ soybean trypsin inhibitor). Total protein concentration was determined by BCA, according to the manufacturer's protocol. Cell lysates were denatured in sample buffer $(50 \mathrm{mM}$ Tris-HCl, pH 6.8, 1\% SDS, 5\% 2-mercaptoethanol, 10\% glycerol, $0.001 \%$ bromophenol blue) and boiled for $5 \mathrm{~min}$. Samples (20 $\mathrm{\mu g}$ total protein) were resolved on reducing 10\% SDS-PAGE, and proteins were transferred to polyvinylidene difluoride (PVDF) membranes for western blot analysis. Rainbow ${ }^{\mathrm{TM}}$ molecular weight markers were run in parallel to estimate molecular weights. Membranes were blocked with 5\% BSA and Tween-20 0.5\%. Primary antibodies were used for immunoblotting. After extensive washing in Tween-TBS, membranes were incubated for $2 \mathrm{~h}$ with the appropriate secondary biotin-conjugated antibody (1:5000). Immunoreactive proteins were visualized using the ECL system. Band densitometry was quantified using Photoshop software (Adobe Systems, San Jose, CA, USA), and values were expressed as arbitrary units (AU).

\subsection{1. $q R T-P C R$ Analysis}

MCF-7 cells $\left(2 \times 10^{5}\right.$ cells/well $)$ were incubated for $48 \mathrm{~h}$ onto MDA-ECM or on their own ECM. Total RNA was extracted using an RNeasy mini kit. cDNA was generated from $1 \mu \mathrm{g}$ RNA using a high capacity cDNA reverse transcription kit. cDNA was amplified with human gene-specific primers for TWIST and $\beta$-actin. Each candidate gene was internally normalized against $\beta$-actin. The relative quantitative value was expressed by the $2^{-\Delta \Delta C t}$ method. qPCR was performed using a 7500/7500 fast real-time PCR system (Applied Biosystems, Foster City, CA, USA), and amplicons were quantified 
using an SYBR ${ }^{\circledR}$ Green PCR master mix kit (Applied Biosystems, Foster City, CA, USA). PCR was performed with a program of $5 \mathrm{~min}$ at $95^{\circ} \mathrm{C}$ and then 45 cycles at $94{ }^{\circ} \mathrm{C}(30 \mathrm{~s}), 60{ }^{\circ} \mathrm{C}(30 \mathrm{~s})$ and $72{ }^{\circ} \mathrm{C}$ (30 s), followed by a standard curve of denaturation.

\subsection{Statistical Analysis}

All the plots inserted in figures represent the mean of at least three independent experiments carried out on different days to reduce any bias. Statistical analysis, unless otherwise stated, was assessed by ANOVA and Student's $t$-test, with $p<0.05$ taken as statistically significant.

\section{Conclusions}

Our data showed that the matrix produced by highly metastatic human breast cancer cells (MDA-MB-231) activated intracellular signaling pathways related to $\alpha v \beta 3$ integrin and potentiated canonical TGF- $\beta$ receptor signaling, inducing an EMT-like phenotype and migration in MCF-7 cells, likely favoring breast cancer metastasis. We believe that this data might contribute to unravel what happens in breast cancer relapses, even in patients that were classified as having luminal type tumors, which are known in the literature to have a better outcome, although this does not happen in all patients. These findings provided novel potential target molecules for antitumor and antimetastatic therapies and also represented an important contribution to the understanding of the adhesion-related mechanisms involved in EMT.

Supplementary Materials: Supplementary materials can be found at http://www.mdpi.com/1422-0067/21/8/2995/ s1.

Author Contributions: Conceptualization, R.M.B.-C. and E.H.-N.; Formal analysis, R.M.B.-C., E.H.-N., A.M.V., P.B.-d.-S., and J.M.-D.; Funding acquisition, C.B.-F.; Investigation, R.M.B.-C.; Methodology, R.M.B.-C., E.H.-N., A.M.V., P.B.-d.-S. and J.M.-D.; Project administration, C.B.-F.; Resources, J.M.-D. and C.B.-F.; Supervision, C.B.-F.; Validation, R.M.B.-C.; Writing-original draft, R.M.B.-C. and E.H.-N.; Writing—review and editing, R.M.B.-C., E.H.-N., and C.B.-F. All authors have read and agreed to the published version of the manuscript.

Funding: This work was supported by Fundação de Amparo à Pesquisa do Rio de Janeiro [FAPERJ E-26/010.001.754/2015; E-26/210.110./2018]; Fundação e Coordenação de Apoio de Pessoal de Nível Superior [CAPES, \#23038.007778/2014-21], and Conselho Nacional de Desenvolvimento Científico e Tecnológico [CNPQ 302413/2017-0].

Conflicts of Interest: The authors declare no competing interests.

\section{Abbreviations}

MCF-ECM Extracellular matrix-derived from the MCF-7 cell line

MDA-ECM Extracellular matrix-derived from the MDA-MB-231 cell line

\section{References}

1. Bertucci, F.; Birnbaum, D. Reasons for breast cancer heterogeneity. J. Biol. 2008, 7, 6. [CrossRef]

2. Pritchard, K.I. Endocrine therapy: Is the first generation of targeted drugs the last? J. Int. Med. 2013, 274, 144-152. [CrossRef]

3. Lynce, F.; Blackburn, M.J.; Cai, L.; Wang, H.; Rubinstein, L.; Harris, P.; Isaacs, C.; Pohlmann, P.R. Characteristics and outcomes of breast cancer patients, enrolled in the National Cancer Institute Cancer Therapy Evaluation Program sponsored phase I clinical trials. Breast Cancer Res. Treat. 2018, 168, 35-41. [CrossRef]

4. Kusuma, N.; Denoyer, D.; Eble, J.A.; Redvers, R.P.; Parker, B.S.; Pelzer, R.; Anderson, R.L.; Pouliot, N. Integrin-dependent response to laminin-511 regulates breast tumor cell invasion and metastasis. Int. J. Cancer 2012, 130, 555-566. [CrossRef] [PubMed]

5. Radisky, D.C. Epithelial-mesenchymal transition. J. Cell Sci. 2005, 118, 4325-4326. [CrossRef] [PubMed]

6. Kalluri, R.; Neilson, E.G. Epithelial mesenchymal transition and its implications for fibrosis. J. Clin. Investig. 2009, 112, 1776-1784. [CrossRef]

7. Zhang, Y.E. Non-Smad pathways in TGFbeta signaling. Cell Res. 2009, 19, 128-139. [CrossRef] 
8. Mamuya, F.A.; Duncan, M.K. aV integrins and TGF- $\beta$-induced EMT: A circle of regulation. J. Cell Mol. Med. 2012, 164, 45-55. [CrossRef]

9. Gonzalez, D.M.; Medici, D. Signaling mechanisms of the epithelial-mesenchymal transition. Sci. Signal. 2014, 7, 344. [CrossRef]

10. Schlaepfer, D.D.; Mitra, S.K. Multiple connections link FAK to cell motility and invasion. Curr. Opin. Genet. Dev. 2004, 14, 92-101. [CrossRef]

11. Anthis, N.J.; Campbell, I.D. The tail of integrin activation. Trends Biochem. Sci. 2011, 36, 191-198. [CrossRef] [PubMed]

12. Katoh, D.; Nagaharu, K.; Shimojo, N.; Hanamura, N.; Yamashita, M.; Kozuka, Y.; Imanaka-Yoshida, K.; Yoshida, T. Binding of $\alpha \mathrm{v} \beta 1$ and $\alpha \mathrm{v} \beta 6$ integrins to tenascin-C induces epithelial-mesenchymal transition-like change of breast cancer cells. Oncogenesis 2013, 2, e65. [CrossRef]

13. Nagaharu, K.; Zhang, X.; Yoshida, T.; Katoh, D.; Hanamura, N.; Kozuka, Y.; Ogawa, T.; Shiraishi, T.; Imanaka-Yoshida, K. Tenascin $\mathrm{C}$ induces epithelial-mesenchymal transition-like change accompanied by SRC activation and focal adhesion kinase phosphorylation in human breast cancer cells. Am. J. Pathol. 2011. [CrossRef] [PubMed]

14. Abu-Tayeh, H.; Weidenfeld, K.; Zhilin-Roth, A.; Schif-Zuck, S.; Thaler, S.; Cotarelo, C.; Tan, T.Z.; Thiery, J.P.; Green, J.E.; Klorin, G.; et al. 'Normalizing' the malignant phenotype of luminal breast cancer cells via alpha(v)beta(3)-integrin. Cell Death Dis. 2016, 7, e2491. [CrossRef] [PubMed]

15. Takayama, S.; Ishii, S.; Ikeda, T.; Masamura, S.; Doi, M.; Kitajima, M. The relationship between bone metastasis from human breast cancer and integrin alpha(v)beta3 expression. Anticancer Res. 2005, 25, 79-83. [PubMed]

16. Flamini, M.I.; Uzair, I.D.; Pennacchio, G.E.; Neira, F.J.; Mondaca, J.M.; Cuello-Carrión, F.D.; Jahn, G.A.; Simoncini, T.; Sanchez, A.M. Thyroid Hormone Controls Breast Cancer Cell Movement via Integrin $\alpha \mathrm{V} / \beta 3 / \mathrm{SRC} / \mathrm{FAK} / \mathrm{PI} 3-\mathrm{Kinases}$. Horm. Cancer 2017, 8, 16-27. [CrossRef]

17. Wirtz, D.; Konstantopoulos, K.; Searson, P.C. The physics of cancer: The role of physical interactions and mechanical forces in metastasis. Nat. Rev. Cancer 2011, 11, 512-522. [CrossRef]

18. Kim, S.H.; Turnbull, J.; Guimond, S. Extracellular matrix and cell signalling: The dynamic cooperation of integrin, proteoglycan and growth factor receptor. J. Endocrinol. 2011, 209, 139-151. [CrossRef]

19. Cichon, M.A.; Radisky, D.C. Extracellular matrix as a contextual determinant of transforming growth factor- $\beta$ signaling in epithelial-mesenchymal transition and in cancer. Cell Adhes. Migr. 2014, 8, 588-594. [CrossRef]

20. Lu, P.; Takai, K.; Weaver, V.M.; Werb, Z. Extracellular matrix degradation and remodeling in development and disease. Cold Spring Harb. Perspect. Biol. 2011, 3, a005058. [CrossRef]

21. Chia, J.; Kusuma, N.; Anderson, R.; Parker, B.; Bidwell, B.; Zamurs, L.; Nice, E.; Pouliot, N. Evidence for a role of tumor-derived laminin-511 in the metastatic progression of breast cancer. Am. J. Pathol. 2007, 170, 2135-2148. [CrossRef] [PubMed]

22. Rudland, P.S.; Platt-Higgins, A.; El-Tanani, M.; De Silva Rudland, S.; Barraclough, R.; Winstanley, J.H.; Howitt, R.; West, C.R. Prognostic significance of the metastasis-associated protein osteopontin in human breast cancer. Cancer Res. 2002, 62, 3417-3427. [PubMed]

23. Hancox, R.A.; Allen, M.D.; Holliday, D.L.; Edwards, D.R.; Pennington, C.J.; Guttery, D.S.; Shaw, J.A.; Walker, R.A.; Pringle, J.H.; Jones, J.L. Tumour associated tenascin-C isoforms promote breast cancer cell invasion and growth by matrix metalloproteinase-dependent and independent mechanisms. Breast Cancer Res. 2009, 11, R24. [CrossRef] [PubMed]

24. Oskarsson, T.; Acharyya, S.; Zhang, X.H.; Vanharanta, S.; Tavazoie, S.F.; Morris, P.G.; Downey, R.J.; Manova-Todorova, K.; Brogi, E.; Massagué, J. Breast cancer cells produce tenascin C as a metastatic niche component to colonize the lungs. Nat. Med. 2011, 17, 867-874. [CrossRef]

25. Pickup, M.W.; Mouw, J.K.; Weaver, V.M. The extracellular matrix modulates the hallmarks of cancer. EMBO Rep. 2014, 15, 1243-1253. [CrossRef]

26. Nam, J.M.; Onodera, Y.; Bissell, M.J.; Park, C.C. Breast cancer cells in three-dimensional culture display an enhanced radioresponse after coordinate targeting of integrin alpha5beta1 and fibronectin. Cancer Res. 2010, 70, 5238-5248. [CrossRef]

27. Kenny, H.A.; Chiang, C.Y.; White, E.A.; Schryver, E.M.; Habis, M.; Romero, I.L.; Ladanyi, A.; Penicka, C.V.; George, J.; Matlin, K.; et al. Mesothelial cells promote early ovarian cancer metastasis through fibronectin secretion. J. Clin. Investig. 2014, 124, 4614-4628. [CrossRef] 
28. Eke, I.; Storch, K.; Krause, M.; Cordes, N. Cetuximab attenuates its cytotoxic and radiosensitizing potential by inducing fibronectin biosynthesis. Cancer Res. 2013, 73, 5869-5879. [CrossRef]

29. Sisci, D.; Aquila, S.; Middea, E.; Gentile, M.; Maggiolini, M.; Mastroianni, F.; Montanaro, D.; Andò, S. Fibronectin and type IV collagen activate ERalpha AF-1 by c-Src pathway: Effect on breast cancer cell motility. Oncogene 2004, 23, 8920-8930. [CrossRef]

30. Benton, G.; Crooke, G.E.; George, J. Laminin-1 induces E-cadherin expression in 3-dimensional cultured breast cancer cells by inhibiting DNA methyltransferase 1 and reversing promoter methylation status. FASEB J. 2009, 23, 3884-3895. [CrossRef]

31. Pal, S.; Moulik, S.; Dutta, A.; Chatterjee, A. Extracellular matrix protein laminin induces matrix metalloproteinase-9 in human breast cancer cell line MCF-7. Cancer Microenviron. 2014, 7, 71-78. [CrossRef] [PubMed]

32. Guerrero, J.; Tobar, N.; Cáceres, M.; Espinoza, L.; Escobar, P.; Dotor, J.; Smith, P.C.; Martínez, J. Soluble factors derived from tumor mammary cell lines induce a stromal mammary adiposereversion in human and mice adipose cells. Possible role of TGF-beta1 and TNF-alpha. Breast Cancer Res. Treat. 2010, 119, 497-508. [CrossRef] [PubMed]

33. Espinoza-Sánchez, N.A.; Vadillo, E.; Balandrán, J.C.; Monroy-García, A.; Pelayo, R.; Fuentes-Pananá, E.M. Evidence of lateral transmission of aggressive features between different types of breast cancer cells. Int. J. Oncol. 2017, 51, 1482-1496. [CrossRef] [PubMed]

34. Hwajin, S.; Aree, M. Epithelial-mesenchymal Transition and Cell Invasion. Toxicol. Res. 2010, 26, $245-252$. [CrossRef]

35. Comşa, S.; Cîmpean, A.M.; Raica, M. The Story of MCF-7 Breast Cancer Cell Line: 40 years of Experience in Research. Anticancer Res. 2015, 35, 3147-3154.

36. Huttenlocher, A.; Horwitz, A.R. Integrins in cell migration. Cold Spring Harb. Perspect. Biol. 2011, 3, a005074. [CrossRef]

37. Hynes, R.O. Integrins: Bidirectional, allosteric signaling machines. Cell 2002, 110, 673-687. [CrossRef]

38. Derynck, R.; Zhang, Y.E. Smad-dependent and Smad-independent pathways in TGF- $\beta$ family signaling. Nature 2003, 425, 577-584. [CrossRef]

39. Helal-Neto, E.; Brandão-Costa, R.M.; Saldanha-Gama, R.; Ribeiro-Pereira, C.; Midlej, V.; Benchimol, M.; Morandi, V.; Barja-Fidalgo, C. Priming Endothelial Cells With a Melanoma-Derived Extracellular Matrix Triggers the Activation of $\alpha v \beta 3 / V E G F R 2$ Axis. J. Cell. Physiol. 2016, 231, 2464-2473. [CrossRef]

40. Marelli, U.K.; Rechenmacher, F.; Sobahi, T.R.; Mas-Moruno, C.; Kessler, H. Tumor targeting via integrin ligands. Front. Oncol. 2013, 30, 222. [CrossRef]

41. Taherian, A.; Li, X.; Liu, Y.; Haas, T.A. Differences in integrin expression and signaling within human breast cancer cells. BMC Cancer 2011, 11, 293. [CrossRef] [PubMed]

42. Juliano, D.; Wang, Y.; Marcinkiewicz, C.; Rosenthal, L.A.; Stewart, G.J.; Niewiarowski, S. Disintegrin interaction with alpha $\mathrm{V}$ beta 3 integrin on human umbilical vein endothelial cells: Expression of ligand-induced binding site on beta 3 subunit. Exp. Cell Res. 1996, 225, 132-142. [CrossRef] [PubMed]

43. Naba, A.; Clauser, K.R.; Whittaker, C.A.; Carr, S.A.; Tanabe, K.K.; Hynes, R.O. Extracellular matrix signatures of human primary metastatic colon cancers and their metastases to liver. BMC Cancer 2014, 14, 514-518. [CrossRef] [PubMed]

44. Foroni, L.; Vasuri, F.; Valente, S.; Gualandi, C.; Focarete, M.L.; Caprara, G.; Scandola, M.; D’Errico-Grigioni, A.; Pasquinelli, G. The role of 3D microenvironmental organization in MCF-7 epithelial-mesenchymal transition after 7 culture days. Exp. Cell Res. 2013, 319, 1515-1522. [CrossRef] [PubMed]

45. BisselL, M.J.; Weaver, V.M.; Lelièvre, S.A.; Wang, F.; Petersen, O.W.; Schmeichel, K.L. Tissue structure, nuclear organization, and gene expression in normal and malignant breast. Cancer Res. 1999, 59, 1757-1763. [PubMed]

46. Thiery, J.P.; Acloque, H.; Huang, R.Y.; Nieto, M.A. Epithelial-mesenchymal transitions in development and disease. Cell 2009, 139, 871-890. [CrossRef]

47. Kalembeyi, I.; Inada, H.; Nishiura, R.; Imanaka-Yoshida, K.; Sakakura, T.; Yoshida, T. Tenascin-C upregulates matrix metalloproteinase- 9 in breast cancer cells: Direct and synergistic effects with transforming growth fator beta 1. Int. J. Cancer 2003, 105, 53-60. [CrossRef] 
48. Ilunga, K.; Nishiura, R.; Inada, H.; El-Karef, A.; Imanaka-Yoshida, K.; Sakakura, T.; Yoshida, T. Co-stimulation of human breast cancer cells with transforming growth factor-beta and tenascin-C enhances matrix metalloproteinase-9 expression and cancer cell invasion. Int. J. Exp. Pathol. 2004, 85, 373-379. [CrossRef]

49. Neubauer, H.; Ruoff, A.; Paessler, N.; Solomayer, E.; Wallwiener, D.; Fehm, T. A laminin-rich basement membrane matrix influences estrogen receptor beta expression and morphology of MDA-MB-231 breast cancer cells. Oncol. Rep. 2009, 21, 475-481.

50. Polyak, K. Heterogeneity in breast cancer. J. Clin. Investig. 2011, 121, 3786-3788. [CrossRef]

51. Midwood, K.S.; Chiquet, M.; Tucker, R.P.; Orend, G. Tenascin-C at a glance. J. Cell Sci. 2016, 129, 4321-4327. [CrossRef] [PubMed]

52. Midwood, K.S.; Orend, G. The role of tenascin-C in tissue injury and tumorigenesis. J. Cell Commun. Signal. 2009, 3, 287-310. [CrossRef] [PubMed]

53. Kadar, A.; Tõkés, A.M.; Kulka, J.; Robert, L. Extracellular matrix components in breast carcinomas. Semin. Cancer Biol. 2002, 12, 243-257. [CrossRef]

54. Saitoh, Y.; Kuratsu, J.; Takeshima, H.; Yamamoto, S.; Ushio, Y. Expression of osteopontin in human glioma. Its correlation with the malignancy. Lab. Investig. 1995, 72, 55-63.

55. Su, L.; Mukherjee, A.B.; Mukherjee, B.B. Expression of antisense osteopontin RNA inhibits tumor promoter-induced neoplastic transformation of mouse JB6 epidermal cells. Oncogene 1995, 10, 2163-2169.

56. Niu, Y.; Zhang, L.; Bi, X.; Yuan, S.; Chen, P. Evaluation of vitronectin Expression in prostate cancer and the clinical significance of the association of vitronectin expression with prostate specific antigen in detecting prostate cancer. Urol. J. 2016, 13, 2527-2532.

57. Levental, K.R.; Yu, H.; Kass, L.; Lakins, J.N.; Egeblad, M.; Erler, J.T.; Fong, S.F.; Csiszar, K.; Giaccia, A.; Weninger, W.; et al. Matrix crosslinking forces tumor progression by enhancing integrin signaling. Cell 2009, 139, 891-906. [CrossRef]

58. Cantley, L.C. The phosphoinositide 3-kinase pathway. Science 2002, 296, 1655-1657. [CrossRef]

59. Liu, P.; Cheng, H.; Roberts, T.M.; Zhao, J.J. Targeting the phosphoinositide3-kinase pathway in cancer. Nat.Rev.Drug Discov. 2009, 8, 627-644. [CrossRef]

60. Bakin, A.V.; Tomlinson, A.K.; Bhowmick, N.A.; Moses, H.L.; Arteaga, C.L. Phosphatidylinositol 3-kinase function is required for transforming growth factor $\beta$-mediated epithelial to mesenchymal transition and cell migration. J. Biol. Chem. 2000, 275, 36803-36810. [CrossRef]

61. Yu, L.; Hébert, M.C.; Zhang, Y.E. TGF- $\beta$ receptor-activated p38 MAP kinase mediates Smad-independent TGF- $\beta$ responses. EMBO J. 2002, 21, 3749-3759. [CrossRef] [PubMed]

62. Chan, K.K.; Matchett, K.B.; McEnhill, P.M.; Dakir, E.H.; McMullin, M.F.; El-Tanani, Y.; Patterson, L.; Faheem, A.; Rudland, P.S.; McCarron, P.A.; et al. Protein deregulation associated with breast cancer metastasis. Cytokine Growth Factor Rev. 2015, 26, 415-423. [CrossRef] [PubMed]

63. Imamichi, Y.; Menke, A. Signaling pathways involved in collagen-induced disruption of the E-cadherin complex during epithelial-mesenchymal transition. Cells Tissues Organs 2007, 185, 180-190. [CrossRef] [PubMed]

64. Jin, H.; Varner, J. Integrins: Roles in cancer development and as treatment targets. Br. J. Cancer 2004, 90, 561-565. [CrossRef] [PubMed]

65. Yoshida, T.; Akatsuka, T.; Imanaka-Yoshida, K. Tenascin-C and integrins in cancer. Cell Adhes. Migr. 2015, 9, 96-104. [CrossRef] [PubMed]

66. Hill, B.S.; Sarnella, A.; Capasso, D.; Comegna, D.; Del Gatto, A.; Gramanzini, M.; Albanese, S.; Saviano, M.; Zaccaro, L.; Zannetti, A. Therapeutic Potential of a Novel $\alpha v \beta_{3}$ Antagonist to Hamper the Aggressiveness of Mesenchymal Triple Negative Breast Cancer Sub-Type. Cancers (Basel) 2019, 11, E139. [CrossRef] [PubMed]

67. Cammareri, P.; Rose, A.M.; Vincent, D.F.; Wang, J.; Nagano, A.; Libertini, S.; Ridgway, R.A.; Athineos, D.; Coates, P.J.; McHugh, A.; et al. Inactivation of TGFbeta receptors in stem cells drives cutaneous squamous cell carcinoma. Nat. Commun. 2016, 7, 12493. [CrossRef]

68. Zhang, H.; Fredericks, T.; Xiong, G.; Qi, Y.; Rychahou, P.G.; Li, J.D.; Pihlajaniemi, T.; Xu, W.; Xu, R. Membrane associated collagen XIII promotes cancer metastasis and enhances anoikis resistance. Breast Cancer Res. 2018, 20, 116. [CrossRef]

69. Tan, F.; Huang, Y.; Pei, Q.; Liu, H.; Pei, H.; Zhu, H. Matrix stiffness mediates stemness characteristics via activating the Yes-associated protein in colorectal cancer cells. J. Cell Biochem. 2018. [CrossRef] 
70. Celia-Terrassa, T.; Kang, Y. Distinctive properties of metastasis-initiating cells. Genes Dev. 2016, 30, 892-908. [CrossRef]

71. Kröger, C.; Afeyan, A.; Mraz, J.; Eaton, E.N.; Reinhardt, F.; Khodor, Y.L.; Thiru, P.; Bierie, B.; Ye, X.; Burge, C.B.; et al. Acquisition of a hybrid $\mathrm{E} / \mathrm{M}$ state is essential for tumorigenicity of basal breast cancer cells. Proc. Natl. Acad. Sci. USA 2016, 116, 7353-7362. [CrossRef] [PubMed] 